BNWL-2208

UC-66

GEOCITY: A COMPUTER CODE FOR

CALCULATING COSTS OF DISTRICT

HEATING USING GEOTHERMAL RESOURCES

by

C.L. MCDonald

C.H. Bloomster

S.C. Schulte

February 1977

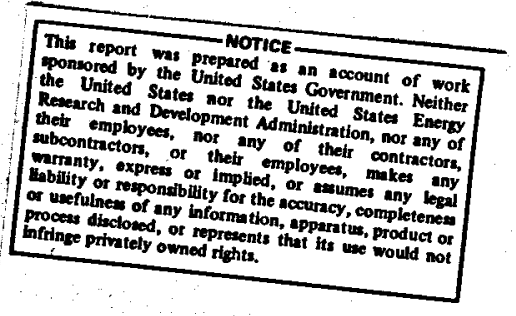




\section{DISCLAIMER}

This report was prepared as an account of work sponsored by an agency of the United States Government. Neither the United States Government nor any agency Thereof, nor any of their employees, makes any warranty, express or implied, or assumes any legal liability or responsibility for the accuracy, completeness, or usefulness of any information, apparatus, product, or process disclosed, or represents that its use would not infringe privately owned rights. Reference herein to any specific commercial product, process, or service by trade name, trademark, manufacturer, or otherwise does not necessarily constitute or imply its endorsement, recommendation, or favoring by the United States Government or any agency thereof. The views and opinions of authors expressed herein do not necessarily state or reflect those of the United States Government or any agency thereof. 


\section{DISCLAIMER}

Portions of this document may be illegible in electronic image products. Images are produced from the best available original document. 


\section{CONTENTS}

LIST OF FIGURES

LIST OF TABLES

SUMMARY

INTRODUCTION

GEOCITY OVERVIEW

DISTRIBUTION SYSTEM MODEL

CITY DEFINITION

DEFINITION OF DISTRICTS

TOTAL FLUID REQUIREMENTS

PIPING NETWORK DESIGN

Pipe Design and Material Requirements

Temperature Calculations

Capital and Operating Costs

Special Options and Capabilities

.iv

Adjustment Factors

THE RESERVOIR MODEL

EXPLORATION AND DEVELOPMENT

DRILLING

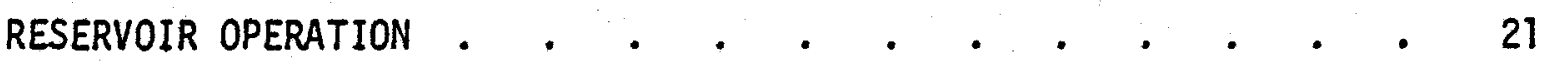

FLUID TRANSMISSION AND DISPOSAL • . . . . . . . . . . 22

CONCLUSIONS • • • • . . . . . . . . . . . . . . 23

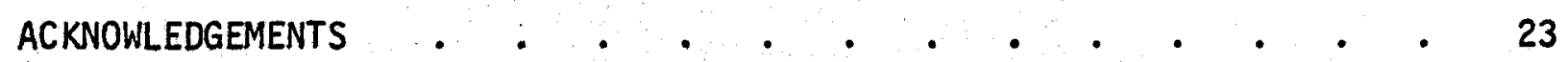

REFERENCES - • • • • • • • • • • • • • • •

APPENDIX A - CAPITAL AND OPERATING COST MODELS FOR

DISTRICT HEATING DISTRIBUTION SYSTEIS

APPENDIX B - DESCRIPTION OF PREDEFINED RESIDENTIAL

TYPES FOR OPTIONAL USE IN THE GEOCITY MODEL. • • • • • •

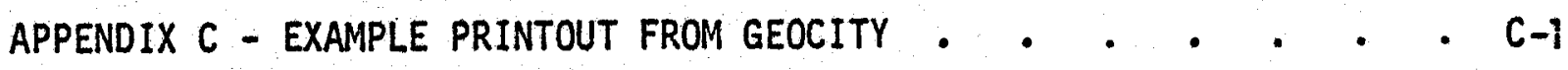




\section{LIST OF TABLES}

1 City Definition Input Parameters . . . . . . . . 9

2 Input Parameters Describing the Districts for a District Heating System . . . . . . . . . . 9

3 Description of the Five Residential District Types Used by the Distribution System Model . . . . . . . 10

4 Design Options for Distribution System Mode1 . . . . . . 13

5 Piping System Design Parameters . . . . . . . . . 14

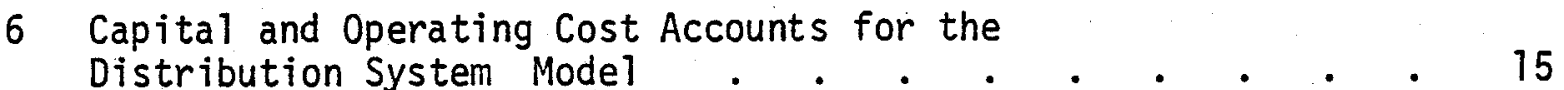

7 Economic Input Parameters for the Distribution System Model . 16

8 Parameters for Special Options . . . . . . . . 16

9 Adjustment Factors for Use with the Distribution System Model . 18

10 Input to Transmission and Disposal Submodels . . . . . 20

A-1 District Heating System Capital Cost Coefficients . . . A-8

A-2 Operating Cost Models . . . . . . . . . . A-32

A-3 Valves and Carbon Steel Fitting . . . . . . . . A-13

A-4 Steel Casing Fitting . . . . . . . . . . A-14

A-5 PVC Casing Fitting . . . . . . . . . . A-15

A-6 Meter. . . . . . . . . . . . . . . A-15

A-7 Cost Factors . . . . . . . . . . . . . A-16

B-1 Design Basis for Suburban Residential House . . . . . 8-2

B-2 Design Basis for High Density Single Family Home . . . . B-3

B-3 Design Basis for Garden Apartment Unit . . . . . . B-4

B-4 Design Basis for Townhouse Unit . . . . . . . . B-5

B-5 Design Basis for High Rise Apartment Unit . . . . . . B-6 


\section{LIST OF FIGURES}

1 Economic Model for Geothermal District Heating Systems . . . 5

2 Logical Relationship of the Elements of the Distribution

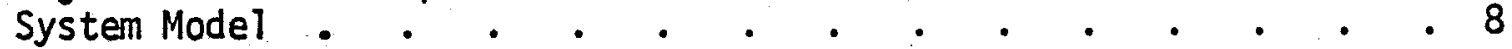

3 Example Layout and Piping Network for a District, with Program Output Describing the Network . . . . . . . 12

A-1 District Heating System Two Pipe Network . . . . . . A-2

B-1 Plan of Suburban Residential House . . . . . . . B-2

B-2 Plan for High Density Single Family Home . . . . . . B-3

B-3 Plan for Garden Apartment Unit . . . . . . . . B-4

B-4 Plan for Townhouse Unit . . . . . . . . . . B-5

B-5 Plan for High Rise Apartment Unit . . . . . . . B-6 


\section{SUMMARY}

GEOCITY is a computer simulation model developed to study the economics of district heating using geothermal energy. GEOCITY calculates the cost of district heating based on climate, population, resource characteristics, and financing conditions. The principal input variables are minimum temperature, heating degree days, population size and density, resource temperature and distance from load center, and the interest rate. From this input data the model designs the transmission and district heating systems. From this design, GEOCITY calculates the capital and operating costs for the entire system, including the production and disposal of the geothermal water.

GEOCITY consists of two major submodels: the geothermal reservoir model and the distribution system model. The distribution system model calculates the cost of heat by simulating the design and the operation of the district heating system. The reservoir model calculates the cost of energy by simulating the discovery, development and operation of a geothermal resource and the transmission of this energy to a distribution center. The submodels can be used independently; that is, the distribution model will accept any source of hot water and the reservoir model will deliver energy to meet any demand.

The distribution system model can simulate many designs for hot water heating systems. These alternative designs include various configurations of heat pumps and/or heat exchangers; different piping system design practices; and the use of different materials for pipe, insulation, and casing.

GEOCITY can simulate nearly any financlal and tax structure through varying the rates of return on equity and debt, the debt-equity ratios, and tax rates. Both private enterprise and municipal utility systems can be simulated. The reservoir model and the distribution model may have the same or differing financial structures and costs of capital. The distribution system and reservoir 11 fe can be varied over a long period, currently up to 50 years. 
GEOCITY calculates the cost of energy based on the principle that the present worth of the revenues will be equal to the present worth of the expenses including investment return over the economic life of the distribution system and/or reservoir. The present worth factor is determined by the capital structure and rates of return on invested capital for the organization.

The models have been designed to enable extensive sensitivity studies to determine the relative effect of different economic and technical parameters, assumptions, and uncertainties on the cost of providing heat. The GEOCITY program can be used to:

- determine the economic incentives for specific research and development programs;

- determine potential economic impacts of uncertainties in resource conditions and technology;

- identify major cost components;

- assess the economic incentive for district heating at specific locations; and

- provide a systematic method for comparing district heating system designs.

Combined with resource assessment, climatic, and demographic information, GEOCITY can be used to define the potential supply curve (price) quanity relationship) for geothermal energy. This supply curve forms the basis for: .1) assessing the potential role of geothermal energy in competition with other sources of energy, and 2) estimating potential economic incentives for new research and development programs. 


\section{INTRODUCTION}

District heating is an area where low quality energy (geothermal heat) can replace high quality energy (fossil fuels and electricity). Geothermal energy is a potentially extensive and inexhaustible energy source. A large fraction of the known geothermal resources consist of medium to low temperature water. The energy available in this water may be efficiently exploited with district heating systems. Economic exploitation depends on the design of the distribution systems and the characteristics of the city, climate and geothermal resource.

Since wide variations are expected in cities, climates and geothermal sources, a computer program called GEOCITY has been developed to systematically calculate the potential cost of district heating using geothermal power. GEOCITY combines engineering design, engineering economy and economic simulation. This provides the capability to evaluate the impacts of heating costs, variations in economic and technical factors, resource conditions, climate, and demographic factors. System components are designed using accepted engineering practice; some component designs are optimized. This report describes GEOCITY; after an overview of the program, the various components are described in detail.

GEOCITY is an offshoot of the GEOCOST computer program, (1) which calculates the cost of generating electricity from geothermal resources. The reservoir model in GEOCITY is taken directly from GEOCOST. The distribution model is derived from a solar energy district heating model obtained from Sandia Laboratories. (a) The GEOCITY program comprises the entire production, distribution, and waste disposal system for geothermal district heating applications, but does not include the cost of radiators, convectors, or other in-house heating systems.

\footnotetext{
(a) B.W. Marshell of Sandia Laboratories generously provided a copy of the code he was developing.
} 


\section{GEOCITY OVERVIEW}

The GEOCITY program consists of design models and deterministic cost models which simulate the construction and operation of a district heating system using a geothermal resource. The design models develop system components based on the characteristics of the resource, climate, city and buildings heated. Capital costs for the components are then determined from cost models. Other cost models provide operating costs. Accounting routines generate the cash flow from capital and operating costs and other economic factors, e.g., taxes, interest rate and rate of return. Using discounted cash flow analysis, GEOCITY calculates the unit cost for district heating. The input data are the wellhead fluid conditions, density and area of zones within the city, description of heat demand of buildings within each zone, climatic conditions and piping system design. GEOCITY includes an economic and technical data file consisting of design parameters and cost and tax data. The code user may use the built-in data or supply any desired changes.

The flow chart for GEOCITY is shown in Figure 1. The two main elements of the program are the reservoir and distribution systems models. Linkage between these two models is provided by the fluid transmission and distribution system demand submodels. Total fluid demand at well head conditions is computed in the demand submodel. The transmission submodel calculates the number of wells required, pipe lengths, and diameters, pumping requirements and the temperature and pressure loss between the reservoir and the distribution system. The program iterates between the distribution system demand submodel, which calculates the additional flow required under the degraded fluid conditions, and the fluid transmission submodel, which provides the additional flow requirements by adding wells and determines the new temperature and pressure drop. Iteration continues until the flow to the distribution system converges within preset criteria.

After the required total fluid flow is established, the cash flow associated with the exploration, development, and operation of the reservoir from the beginning of exploration through the life of the distribution system is determined. From the cash flow, the required revenue from energy sales and 


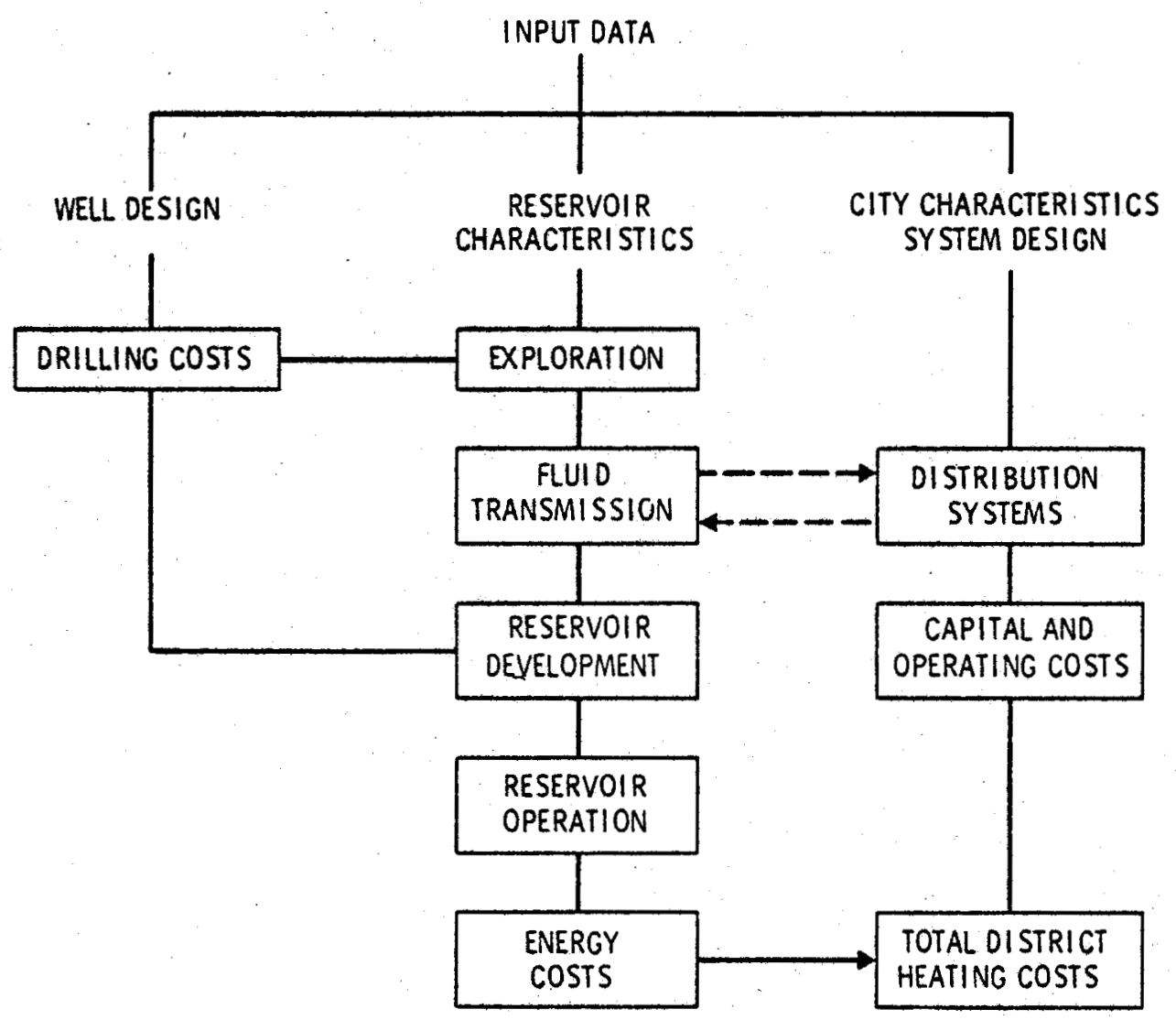

FIGURE 1. Economic Model for Geothermal District Heating Systems

the unit cost of energy from the reservoir are determined. The GEOCITY program solves for the unit cost of energy by equating the present worth of the revenues and expenses over the useful 11 fe of the distribution system.

The distribution system model designs a piping network for each zone within a city and calculates fluid conditions in each segment of the piping network. Capital and operating cost models are then used to determine the cash flow for the construction and operation of the distribution system. The revenue to the reservoir model is the energy cost to the distribution system and is included in the cash flow for the distribution system. From the distribution system cash flow, the required revenue and unit cost of heat are determined. 
The GEOCITY program allows specifying any debt-equity ratio, any rate of return on equity, and any rate of interest on bonds. Either municipal utility or private enterprise financing and accounting can be selected. The program incurs debt and equity at the specified ratio when expenses exceed revenues, and repays debt and equity in the same ratio when revenues exceed expenses. At the end of each project, debt and equity are exactly repaid and the project exactly earns the specified rate of return.

The reservoir and distribution systems models are discussed in more detail in later sections. The distribution system capital and operating cost models are described in Appendix $A$. The residential zones included in the GEOCITY data file are described in Appendix $B$. Appendix $C$ includes an example case showing typical input and output from the program. 


\section{DISTRIBUTION SYSTEM MODEL}

The distribution system model simulates the design, construction, and operation of a district heating distribution system. For this simulation, hot water is purchased from the operator of the geothermal reservoir. The distribution system model includes submodels which 1) design a distribution system for a city by considering building densities, heat demands, and climatic data; 2) calculate head and heat losses for the system; 3) estimate equipment and material requirements; and 4 ) estimate construction, operating and maintenance costs.

A city consists of districts with relatively homogeneous heat demand density. Each district is defined by describing the heat and hot water demand of typical building units, the density of buildings, the area of the district and two parameters describing the shape of this district. From this information, a piping network is designed. Heat demand data and climatic data are used to determine the water requirements for each building. Working down the piping network, water requirements are used as a basis in selecting the economic pipe size for each segment of the network. Material requirements, heat losses, and head losses are determined for each segment of the piping network. Construction, material and operating costs, and costs for pumps, meters, and control equipment are derived based on the distribution system design.

Each component of the distribution systems model is described in the following paragraphs. The logical relationships between the model components are illustrated in Figure 2.

\section{CITY DEFINITION}

The city is defined by its distance from the geothermal reservoir, its climatic characteristics, and the number of districts within the city. The input parameters which may be used in describing the city are listed in Table 1. Most of the details needed for design of the actual piping system are derived from the definitions of the districts. The distance from the reservoir to the city is used in designing the fluid transmission line and 


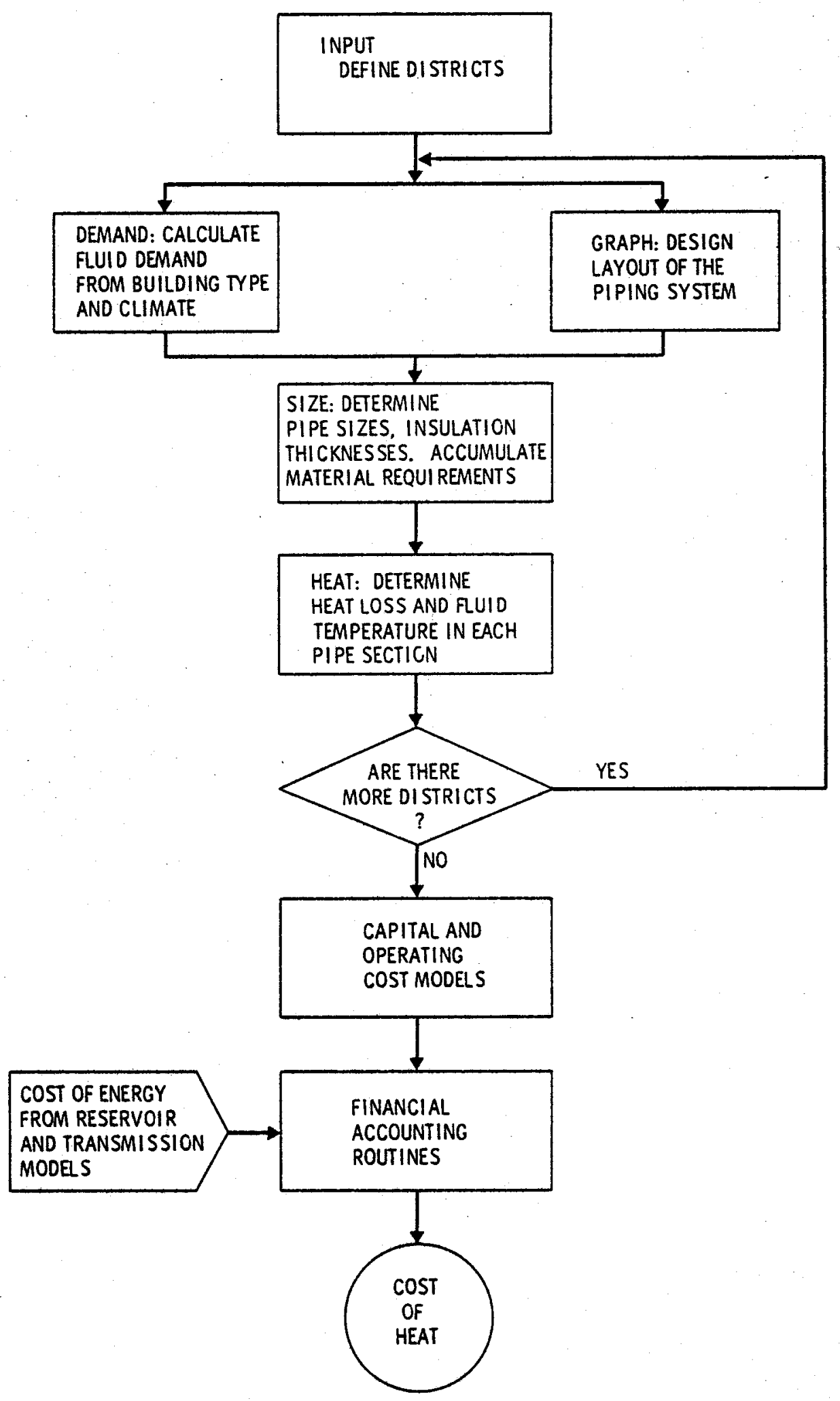

FIGURE 2. Logical Relationship of the Elements of the Distribution System Model 
TABLE 1. City Definition Input Parameters

Climatic. Parameters

Actual degree days

Design degree days

Maximum degree days

Minimum temperature

Design temperature
City Parameters

Distance to reservoir from city

Number of districts

in city

calculating the fluid temperature and pressure entering the distribution system. The climatic parameters are used in determining the distribution of the demand, peak demand, average demand, the load factor, and supplemental heat requirements.

\section{DEFINITION OF DISTRICTS}

A city is described by disaggregating it into districts. A district is a contiguous area consisting of buildings of relatively similar heat demand and uniform density. Districts are defined by the input parameters listed in Table 2.

TABLE 2. Input Parameters Describing the Districts for a District Heating System

District

Definition Parameters

Type of district

Area of district

Width of district

Length of district

Length of the main

Elevation of district above the distribution center

Demand growth rate during system life
District Type Parameters Density of units Peak heat demand per unit Hot water demand per unit Reject temperature Oiversity factor Number of residents per unit 
Districts are the basic element of the distribution system model. Fluid requirements are computed, and the piping networks are designed for each district. Material requirements and costs are also calculated for each district and are totaled for the city.

District type parameters determine the heat demand density and fluid requirements to individual buildings, while district definition parameters define the area, shape, and location of the districts. Several districts may be of the same type. Each type of district is defined only once, and the. type designation is included in the district definition parameter list. For example, several suburban residential areas may have the same density, peak heat demand and hot water requirements. These could be defined by a single suburban district type. Then each district would be defined by including this suburban district type in the district parameter 1 ist.

Five district types, representing typical residential areas, have been identified and defined. These district types are described in Table 3 . Most residential areas in the United States can be described by one of these district types. Variations of the district types in Table 3 or additional district types can also be defined through input. Bases and assumptions for the defined district types are included in Appendix $B$.

TABLE 3. Description of the Five Residential District Types Used by the Distribution System Model(a)

\begin{tabular}{|c|c|c|c|c|c|c|c|}
\hline District Type & $\begin{array}{c}\text { Density } \\
\text { (Buifdings/ } \\
\text { sq. mile) } \\
\end{array}$ & $\begin{array}{l}\text { Building } \\
\text { Peak Heat } \\
\text { Oemand } \\
\text { (MBtu/hr) }\end{array}$ & $\begin{array}{c}\text { Building } \\
\text { Hot Water } \\
\text { Demand } \\
\text { (gallons/ } \\
\text { day) } \\
\end{array}$ & $\begin{array}{c}\text { Reject } \\
\text { Temperature (b) } \\
\begin{array}{c}\left({ }^{\circ} \mathrm{F}\right) \\
\end{array}\end{array}$ & Per Unit & $\begin{array}{l}\text { Number of } \\
\text { Residences } \\
\text { Per Unit } \\
\end{array}$ & $\begin{array}{r}\text { Floor Area } \\
\text { (sq. ft/ } \\
\text { Residence) } \\
\end{array}$ \\
\hline Suburban & 2560 & .053 & 60 & 100 & 3.2 & 1 & 1620 \\
\hline $\begin{array}{l}\text { High Denstty } \\
\text { Single Family }\end{array}$ & 4480 & .034 & 55 & 100 & 3.2 & 1 & 1000 \\
\hline $\begin{array}{l}\text { Garden } \\
\text { Apartments }\end{array}$ & 293 & 1.38 & 3030 & 100 & 162 & 60 & 990 \\
\hline $\begin{array}{l}\text { Townhouses or } \\
\text { Rowhouses }\end{array}$ & 373 & .9 & 1515 & 100 & 81 & 30 & 1012 \\
\hline $\begin{array}{l}\text { High Rise } \\
\text { Apartments }\end{array}$ & 385 & 1.728 & 5400 & 100 & 324 & 108 & 780 \\
\hline
\end{tabular}

(a) Any of these values may be changed through input.

Heat demand is based on $65^{\circ} \mathrm{F}$ inside temperature, $-5^{\circ} \mathrm{F}$ outside temperature and $15 \mathrm{mph}$ wind. 


\section{TOTAL FLUID REQUIREMENTS}

Fluid requirements are calculated for each district as a function of peak heat demand, density, area, specified temperature drop, climate and sanitary hot water requirements. The total city requirement is the sum of the district requirements. It is assumed that $1 / 7$ of the total daily hot water consumption occurs at the same time as the hourly peak heat demand, i.e., in morning or afternoon when people turn up thermostats and use hot water for washing and meal preparation.

Initially, fluid requirements are calculated using the wellhead temperature. The reservoir and transmission line is then designed to meet the fluid demand. The fluid degradation (temperature and pressure) in the transmission line is calculated, and the fluid requirements are recalculated using the degraded temperature. If the new demand changes by more than the given percentage (2\%), the reservoir and transmission line are redesigned using the new fluid demand. This is repeated until the convergence criterion is satisfied.

\section{PIPING NETWORK DESIGN}

The piping network is based on a rectangular grid system in which a building is associated with each grid point. The number of buildings is the product of the density and the area for the district. Buildings are assigned to grid points a row at a time until all of the buildings have been assigned. The ratio of rows to columns is the same as the ratio of length to width specified in the input district descriptions. Each pair of columns is then assigned to a street pipe. If there is an odd column left, two short streets are created, one on each side of the rectangle. A lateral pipe connecting all of the street pipes is created at the midpoint of the streets. At the midpoint of the lateral a main is created which joins the district to the other districts. An example network design and output from GEOCITY are illustrated in Figure 3.

Pipe Design and Material Requirements

Starting at the building farthest from the main, the fluid requirements for that point are calculated and pipe size is determined. Proceeding to 


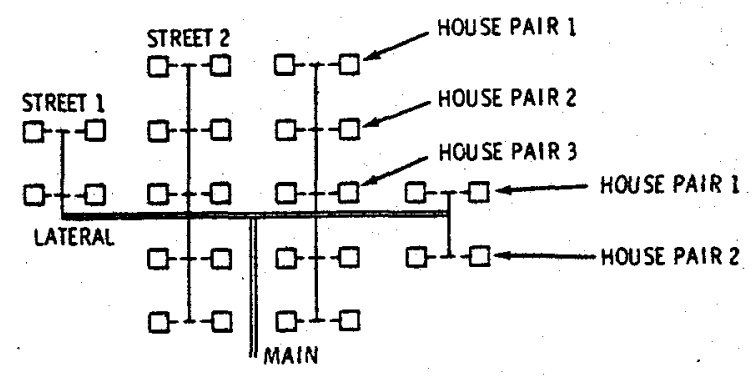

LAYOUT IS FOR A OISTRICT WITH 28 BUILDINGS: THE PIPING NETWORK IS SYMMETRICAL ABOUT THE MAIN AND THE LATERAL. BELOW IS A SAMPLE OUTPUT FROM GEOCITY OESCRIBING THIS NETWORK.

DISTRIBUTION SYSTEM OF DISTRICT 3 SINGLE PIPE SYSTEM

\begin{tabular}{|c|c|c|c|c|c|c|c|}
\hline HOUSE DESCRIPTION & $\begin{array}{l}\text { FLOW RATE } \\
(\mathrm{ib} / \mathrm{sec})\end{array}$ & $\begin{array}{l}\text { HEAT LOSS } \\
\text { (BTU/SEC) }\end{array}$ & $\begin{array}{l}\text { TEMFER } \\
\text { SUPPLY } \\
\end{array}$ & $\begin{array}{l}\text { TURE (F) } \\
\text { RETURN }\end{array}$ & $\begin{array}{c}\text { HEAD LOSS } \\
\text { feet }\end{array}$ & $\begin{array}{l}\text { NOMINAL } \\
\text { OIA (in.) }\end{array}$ & $\begin{array}{l}\text { INSUL } \\
\text { (in.) }\end{array}$ \\
\hline HOUSE & 2.0 & -0.2 & 194 & 123 & 8.86 & 2.00 & 2.0 \\
\hline
\end{tabular}

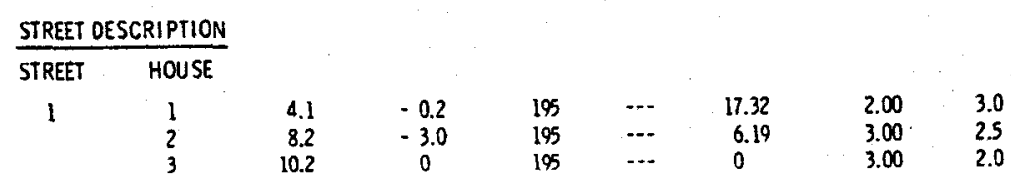

\begin{tabular}{|c|c|c|c|c|c|c|c|c|}
\hline \multicolumn{9}{|c|}{ LATERAL DESCRIPTION } \\
\hline LATERAL & STREET & & & & & & & \\
\hline 1 & $\begin{array}{l}1 \\
2\end{array}$ & $\begin{array}{r}8.2 \\
28.7\end{array}$ & $\begin{array}{l}-5.0 \\
-3.3\end{array}$ & $\begin{array}{l}195 \\
195\end{array}$ & $\cdots$ & $\begin{array}{l}12.05 \\
17.20\end{array}$ & $\begin{array}{l}3.00 \\
4.00\end{array}$ & $\begin{array}{l}3.5 \\
3.0\end{array}$ \\
\hline \multicolumn{9}{|c|}{ MAIN OESCRIPIION } \\
\hline$M A$ & & 57.3 & -13.1 & 195 & -- & 7.38 & 14.00 & 3.5 \\
\hline
\end{tabular}

FIGURE 3. Example Layout and Piping Network for a District, with Program Output Describing the Network

the next pipe intersection toward the main, total fluid flow for that intersection is computed and the pipe is sized. Due to the high degree of symmetry in the network, only a few pipe intersections need to be considered to size the whole pipe network. For example, in Figure 2 the pipe for the network is sized by considering only seven sections. Optimal pipe diameter is selected for each section by minimizing the sum of the annualized capital cost of pipe, insulation, casing, valves, fittings, pumps and trenching and the annual costs of heat loss and pumping power costs. The optimization scheme is a simple search of a restricted set of feasible pipe sizes. Insulation thickness is optimized by considering the value of lost heat, cost of insulation, and increased casing costs. 
Many material and configuration options for pipe, conduit, and insulation are possible. These design options are summarized in Table 4.

Material requirements including pipe, insulation, casing, valves, fittings and meters are accumulated at each pipe intersection. The design options determine which capital cost models are used for the respective system components. Detailed discussion of the capital cost models for the system components is included in Appendix A. Input parameters used to design the piping network are listed in Table 5.

TABLE 4. Design Options for Distribution System Mode1

Pipe Options

1. Two pipes, supply insulated only

2. Two pipes, bundle insulated

3. Two pipes, both insulated separately

4. Two pipes, each insulated and in separate conduit

5. Two pipes, supply insulated, each in separate conduit

6. Single pipe, insulated

1. Carbon -steel, schedule 40

2. Fiberglass reinforced plastic

Insulation Options

1. Calcium silicate

2. Polyurethane foam

Conduit Options.

1. Steel, prefabricated, Class A

2. Plastic (PVC), prefabricated

3. Concrete, field constructed 
TABLE 5. Piping System Design Parameters

Pipe Option

Design Parameters

Pipe Material Option

Insulation Option

Conduit Option

Annular Air Space Size

Burial Depth

Thermal Conductivities of:

- Pipe

- Ground

- Insulation

Ground Temperature

Age Factor for Pipe Roughness

Combined Motor and Pump Efficiency

Temperature Calculations

Heat loss and temperatures are calculated for each pipe section starting at the main and following the pipes to the points farthest from the main. If the system includes a return pipe, heat losses and temperatures are also calculated for every return pipe segment. Parameters used in the heat loss calculations are listed with the design parameters in Table 5 . Heat loss calculations assume a single straight pipe buried in soil, with insulation, an annular air space and casing. It is assumed that the soil temperature remains undisturbed at a radius equal to the pipe burial depth.

\section{Capital and Operating Costs}

Capital and operating costs for the accounts listed in Table 6 are computed from cost models. Detailed discussion of these cost models is in Appendix A. A discounted cash flow accounting scheme is used to calculate the price of heat. The price of heat is determined so that the bonds and/or the specified return on equity are exactly satisfied at the end of the project life. The geothermal reservoir and transmission system can be operated as a separate entity from the district heating system. In this case, the district heating system purchases heat from the reservoir and transmission line operator. Alternatively, the entire system can be treated as an integral unit. 
TABLE 6. Capital and Operating Cost Accounts

for the Distribution System Model

\section{Capital Cost Accounts}

Pipe

Insulation

Casing

Valves

Meters

Pumps

Expansion Loops

Trenches
Fittings

Metering and Control Equipment

Buildings

House Retrofit (optiona 1)

Heat Pump (optional)

Storage (optional)

Heat Exchanger (optional)

Engineering and Administration

Operating Cost Accounts

Operating Expenses

Maintenance

Pump Operation

Meter Readers

Bond Interest

Gross Revenue Tax
State Income Tax

Property Tax and Insurance

Federal Income Tax

Heat Pump Operation (optional)

Heat Exchanger Operation (optional)

Supplemental Heat Cost

Input parameters for the economic analysis are listed in Table 7 . The leakage, supplemental heat cost, and cost of electricity are used by the operating cost models. Trenching difficulty, building retrofit, and heat pump capital costs modify the capital cost accounts. Based on the number of years of construction and operation, annual cash flows are determined. Using a discounted cash flow analysis, the cost of heat to meet the required taxes, rate of return, and bond interest payments is calculated. State taxes are deducted from Federal taxes. The discount rate is determined from the rate of return on equity, bond interest rate, and the capital structure. Plant capital costs, including interim capital replacements, are recovered through the depreciation account.

\section{Special Options and Capabilities}

Options and adjustment factors have been incorporated into the distribution system model to make it useful for specialized studies and situations. Using these options one can study the effects of 1) designing capacity to meet different growth rates in demand, 2) using heat pumps or heat exchangers, and 3) designing different storage capacities. Parameters for the special options are summarized in Table 8. A short discussion of each of the available options follows. 
TABLE 7. Economic Input Parameters for the Distribution System Model

Percentage of Fluid Lost by Leakage Cost of Electricity

Supplemental Heat Cost Trenching Difficulty Factor Cost of Retrofitting Buildings

Heat Pump Capital Cost

Number of Years of Construction

Number of Years of Operation

Depreciable Plant Life

Startup Year for Distribution System

Interim Capital Replacement Rate
Property Insurance Rate

Property Tax Rate.

Bond Interest Rate

Earning on Equity after Taxes Rate

State Gross Revenue Tax Rate

State Income Tax Rate

Federal Income Tax Rate

Fraction of Investment in Bonds

Depreciation Option

- Straight Line

- Sum of Years Digits

TABLE 8. Parameters for Special Options

Growth

Total demand growth over study period (\%) by district Number of years in which growth occurs

Heat Pump Option by District

1 - heat pump at reservoir

2 - heat pumps on mains to districts

3 - heat pumps at individual buildings

4 - no heat pump

Temperature at heat pump outlet $\left({ }^{\circ} \mathrm{F}\right)$

Coefficient of performance

Heat pump capital cost

Heat Exchange Option

1 - heat exchanger

2 - no heat exchanger

Geothermal fluid temperature drop in heat exchanger Circulating water temperature in

Circulating water temperature out

\section{Storage Option}

1 - storage as number of days demand

2 - storage as number of gallons

3 - no storage

Storage capacity (days or gallons depending on option) 
When designing a district heating system, it is often desirable to design for growth in demand since it may be costly to replace pipes too small to meet future demand. The distribution system model will design the piping network for each district to 1) meet only current demand, 2) meet future demand including all pipes to future demand points, and 3) design only the mains and laterals with sufficient capacity to meet future growth. Total demand in each district may grow a different rate. If growth options are used, growth in annual operating, additional annual capital costs and growth in annual heat sales are factored into the accounting routines.

Geothermal resources of very low temperature (less than $120^{\circ} \mathrm{F}$ ) may be used in conjunction with heat pumps. Use of heat pumps with a constant temperature source could lower the operating cost of the heat pump by allowing it to always operate in its most efficient range. Heat pumps may also be used to boost the water temperature for service to commercial or residential buildings. Three heat pump configurations are available; heat pumps can be located at the geothermal reservoir, at the main for each district or at each building. Capital costs must be supplied, but operating costs are calculated based on the input value of the coefficient of performance and the cost of electricity.

Heat exchangers are used because either the temperature of geothermal fluid needs to be reduced or the fluid's chemical composition makes it undesirable for use in a distribution system. A tube and shell heat exchanger is designed to meet the specified temperature changes. Capital costs are calculated as in GEOCOST. (2) It is assumed that the heat exchanger is located at the geothermal reservoir, but owned by the district heating system operator.

Storage capacity may be used to meet demand surges, emergencies, or to reduce the peak capacity requirements of the transmission line and reservoir. Storage options include specifying either the volumetric capacity or the number of days of demand. Capital costs and effects of storage on transmission line and reservoir are factored into the accounting routines. 


\title{
Adjustment Factors
}

Adjustment factors have been included to allow a way of studying situations quite different from the norm. Available adjustment factors are listed in Table 9.

For areas with large elevation differences, it is possible to specify the relative elevation of each district, to be used when designing the pump and estimating the operating costs. Trench digging costs vary depending on terrain, ground conditions, current use and other buried utilities. The trench difficulty factor allows the user to adjust for cost-related factors.

\author{
TABLE 9. Adjustment Factors for Use with \\ the Distribution System Mode1 \\ Elevation differences by district \\ Trench difficulty factor \\ Leakage \\ Age factor for pipe roughness
}

The amount of leakage expected in the system can also be specified. Head losses in the distribution system are calculated based on the roughness of pipe that is about 10 years old. The roughness factors can be changed through input to handle other cases. 


\section{THE RESERVOIR MODEL}

The reservoir model simulates a firm which explores for, discovers, develops, and operates a geothermal reservoir. The components of the energy costs supplied by the reservoir to the distribution system are computed and shown separately from the distribution system. This permits independent parametric analyses for the reservoir. The reservoir model includes submodels for simulating exploration and development costs, fluid transmission and disposal costs, drilling costs, and reservoir operating expenses.

\section{EXPLORATION AND DEVELOPMENT}

The exploration submodel simulates the process by which a geothermal resource would be identified and evaluated. The exploration model reduces the process to a series of discrete steps which have costs and success ratios assigned to them. These steps are 1) identification of target areas, 2) preliminary land check, 3) preliminary geologic reconnaissance, 4) detailed land check and geologic reconnaissance, 5) identification of drillable sites, 6) exploratory drilling, 7) identification of the producible resource and 8) development.

Each of these eight major areas includes a time function, associated costs, decision points, and success ratios (finding rates). The reference cost values and finding rates are assigned on the basis of industry estimates. However, these values and rates are variable and sensitivity analyses can be performed to evaluate their relative importance.

In the present submodel the discrete steps occur sequentially in time with some specified time overlap. Each one of the steps may contain several substeps which parallel each other in time.

Al1 reservoir exploration costs are initially capitalized. As the sites are classified unfavorable through the success ratios, the costs which pertain to those sites are expensed. The remaining capitalized costs for the favorable site are recovered through a cost depletion account (analogous to straight line depreciation) throughout the producing life of the district heating system. 
The reservoir development submodel simulates the field development of the proven geothermal reservoir identified by the exploration submodel. This submodel accumulates all costs associated with reservoir development; these costs include drilling, fluid transmission, and fluid disposal. The development submodel allows specifying the percentage of nonproducing (dry) wells, capacity of injection wells, geometry of the well field, and the fraction of excess producing wells. Input data are shown in Table 10.

\section{TABLE 10. Input to Transmission and Disposal Submodels}

Input Required for A11 Geothermal Plant Types (a)

Average well flow rate $\left(1 b_{\mathrm{m}} / \mathrm{sec}\right)$

Well spacing (acres)

Wellhead fluid temperature $\left({ }^{\circ} \mathrm{F}\right)$

Well life (yr)

Fraction nonproducing wells

Fraction excess producing wells

Transmission maintenance factor

Disposal maintenance factor

Fraction of pipe that can be salvaged

Ratio of injection/production well flow rate

Distance from city to injection wells (m)
Typical Value

40

20

120

20

0.2

0.2

0.05

0.05

0.10

2

(a) Also includes built-in data base for computing well layout design, pipe schedule, pipe cost, insulation cost, cost of valves, gauges, separators, flashers, electric motors, and booster pumps; also data base for computing nodal temperature drop, nodal pressure drop, and electrical power required by booster pumps. 
Reservoir development costs include only those costs required to develop and provide the energy supply to the specified distribution system; if the reservoir could support several distribution systems, the costs of providing the energy supply to each would be treated separately.

DRILLING

Well drilling cost may be input directly or calculated. A submodel was developed for calculating drilling costs for geothermal wells as a function of the well depth, size of the well at the well bottom, the fraction of the well cased, and the hardness of the material being drilled. The component cost breakdown splits costs into tangible and intangible parts because tax regulations may treat these costs differently.

The GEOCITY program treats producing, nonproducing (dry), and injection wells differently. The tangible part of the producing wells is capitalized and expensed through a depreciation account. The intangible part may be either capitalized or expensed immediately. Nonproducing wells are expensed. All costs, both the tangible and intangible, for injection wells are capitalized; these costs are recovered through the depreciation account.

\section{RESERVOIR OPERATION}

The operation submodel simulates the operation of the required reservoir capacity throughout the life of the distribution system. It is composed of several annual costs, e.g., royalty payments, injection costs, taxes, overhead and management, and well maintenance. The operations submodel also includes operating costs for the transmission and disposal systems as well as replacement well drilling and redrilling costs. All of the operating costs are assumed to be constant each year throughout the life of the powerplant. As with reservoir development costs, operating costs refer only to a single distribution system. All annual operating costs are expensed except interim capital replacements. These are capitalized and recovered through the depreciation account. The capitalized part of replacement wells is treated analogously to interim capital replacements. The expensed part of replacement wells is treated as an operating expense. 
FLUID TRANSMISSION AND DISPOSAL

The fluid transmission submodel simulates the conduction of the hot water from the well head to the distribution system. This submodel calculates the pipeline diameter, length, number of producing wells required, the well field layout, pumping requirements, and the costs of the transmission piping system, pumps, and associated equipment. It also calculates the fluid temperature, pressure, viscosity, density, and enthalpy on a nodeby-node basis during transport from the wellhead to the city.

The disposal submodel is analogous to the transmission submodel and simulates the conduction of water effluent from the city to the injection well field. Disposal into a sewage system or river can also be simulated. It calculates the effluent pipeline diameter and length, number of injection wells, injection well field layout, and the costs of the disposal piping system and associated equipment.

The initial costs for the transmission and disposal systems are capitalized. Cost recovery is through the depreciation account using the sum-ofthe-year's digit method. 


\section{CONCLUSIONS}

GEOCITY has been developed to study the effects of different economic and technical parameters, assumptions, and uncertainties on the cost of providing district heat from a geothermal resource. GEOCITY can determine the economic incentives for research and development on geothermal resources, identify costs and assess incentives for a specific site, compare different heating system designs, and allows for uncertainties in resource conditions and technology. GEOCITY is another tool for assessing the value of geothermal energy.

\section{ACKNOWLEDGEMENTS}

The authors gratefully acknowledge the technical contributions of Tim Kula, Lynn Burke and other BNW staff members involved in this program. The technical review and evaluation of the program by Dr. Gordon Reistad, University of Oregon, is appreciated. The help of Bruce Marshell, Sandia Laboratories, by providing a copy of his solar district heating code is also greatly appreciated. The editorial assistance of Betsy Owzarski was most helpful. 
1. C. H. Bloomster, GEOCOST: A Computer Program for Geothermal Cost Analysis, BNWL-1888, February 1975, and

H. D. Huber, C. H. Bloomster, and R. A. Walter, User Manual for Geocost Volume 1, Steam Cycle Version, BNWL-1942 V1, November 1975.

2. H. D. Huber, C. H. Bloomster, and R. A. Walter, User Manual for GEOCOST Volume 2, Binary Cycle Version, BNWL-1942 V2, March 1976, and

Paul H. Cohn and C. H. Bloomster, Capital Cost Models for Geothermal Power Plants, BNWL-1990, July 1976.

3. Owen S, Lieberg, High Temperature Water Systems, Industrial Press, 1958, New York, NY.

4. District Heating Handbook, 3rd Edition, National District Heating Association, Pittsburgh, PA, 1951.

5. Paul L. Geiringer, High Temperature Water Heating, John Wiley and Sons, New York 1963.

6. Underground Heat Distribution Systems, Report No. 30R-64 by Task Group T-54, Building Research Advisory Board, National Academy of SciencesNational Research Council, 1964.

7. ASHRAE 1970 Guide and Data Book. 
APPENDIX A

CAPITAL AND OPERATING COST MODELS FOR DISTRICT HEATING DISTRIBUTION SYSTEMS 
APPENDIX A

CAPITAL AND OPERATING COST MODELS FOR

DISFRICT HEATING DISTRIBUTION SYSTEMS

As pipes are sized for each segment of the distribution network, capital cost models are used to price the piping string and associated components. The capital cost models are primarily functions of pipe size and design options, although other parameters are used in many of the models. Other capital cost models and operating cost models are used for pumps, instrumentation, operating expenses, and taxes.

This appendix describes the cost models in three sections: capital cost models, operating cost models, and cost model equations. The first two sections describe the bases and assumptions used in the models. The third section lists the equations or cost tables used. Each cost model is associated with an account in which the costs are accumulated.

\section{CAPITAL COST MODELS}

Costs are calculated for the entire piping system up to the outer wall of housing units. The basic design is a two-pipe network (Figure A-1). A two-pipe network includes both a supply and a return pipe for each building. The cost models also apply to one-pipe networks which have only a supply pipe for each building.

The total piping bundle is called a conduit. The conduit consists of one or more pipes, which may be insulated, enclosed by the casing.

Depending upon the pipe option, insulation option, conduit option, and material option chosen, applicable component cost models are selected, and costs generated. Component costs are then added to give total piping system capital costs. Fittings and valves are costed at each pipe intersection. 


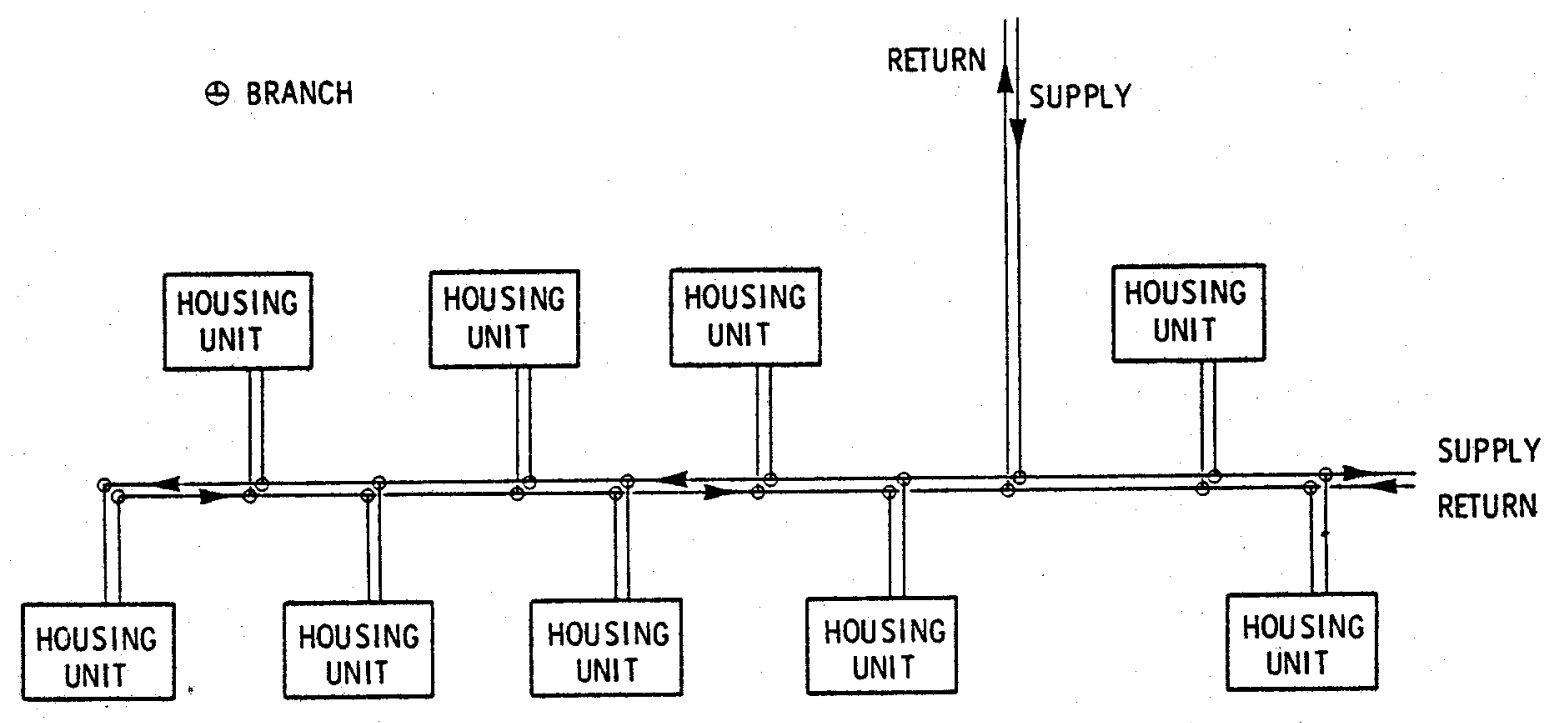

FIGURE A-1. District Heating System Two Pipe Network (shown without expansion loops)

Pipe

Optimal pipe diameter is selected for each segment of the piping network by minimizing the sum of the annualized capital cost of pipe, fittings, insulation, casing valves, pump capacity and the annual costs of heat loss and pumping. Head losses are based on correlations for aged pipe. The default valve assumes a pipe age of 10 years, but the value can be changed through the input data. Pipe may be either carbon steel, schedule 40, or fiberglass reinforced plastic (FRP) depending on the pipe material options.

The pipe account includes only the material cost for straight lengths of pipe.

\section{Insulation}

Optimal insulation thickness is that which produces minimum annual costs of insulation and casing and heat loss values. Either polyurethane foam or calcium silicate insulation can be specified. Insulation is assumed to be factory installed unless foam insulation and field erected concrete casing is specified. For that situation, it is assumed that the insulation is foamed in place.

The insulation account includes material and labor cost for insulating straight pipe lengths and pipe fittings. 
Casing

The smallest standard casing size that will contain the pipe(s), insulation, and annular air space is selected for each segment of the piping network. Casing may be either felt and tar wrapped steel, polyvinyl chloride (PVC) or concrete. Concrete casing is assumed to be a field constructed rectangular box.

The casing account includes costs of material, labor for placing the pipe(s) in the casing, warehousing, transportation, field placement, and alignment of the casing sections.

\section{Fittings}

Two pipe fittings and one casing fitting, sized according to the pipe and casing, are accumulated at each pipe intersection. Two additional fittings are accumulated for each pipe into a building.

The fitting account includes both material cost for the fittings and labor for field connection of the pipes and casing sections.

Expansion Loops

One expansion loop is located in each $300 \mathrm{ft}$ segment of the piping network. The size of the loop is calculated as a function of pipe diameter. Expansion loop cost is the sum of the pipe, fitting, insulation casing, trench and installation costs. Each of these component costs for the expansion loops are calculated separately as described previously and then summed.

The expansion loop account includes all labor and material costs associated with the expansion loop.

Trench

The trench model assumes slopes of $1 / 2$ to 1 in damp sandy loam. Sifted fill material is hauled to the site. The casing is laid on 2 to 4 in. of sifted fill and is covered to a depth of 4 in. with hand placed and tamped sifted fill material. The rest of the trench is then filled and packed by dozer. The top of the casing will be at the specified burial depth below the surface. A trenching difficulty factor may be specified through input to reflect unusual circumstances. 
The trench account includes excavation, purchase and delivery of sifted fill, hand filling and tamping, and dozer filling and packing costs.

Valves

One valve, sized according to the larger pipe size, is located at each pipe intersection. Screwed valves are used when the nominal pipe size is less than $2.5 \mathrm{in}$. Larger sized valves are flanged. The valve is assumed to be a forged steel ball type.

The valve account includes valve, mating flange, bolt-up, handling, insulation, casing and field connection costs.

Meters

One meter is located at each building. Meters are sized according to the expected range of flowrates.

The meter account includes meter, connections, and installation labor costs.

Pumps

One pump and a standby pump are located in each district. The pump is sized to overcome the total head loss and pump the district fluid requirements. Pump motor size is determined from the hydraulic horsepower and the input pump and motor efficiency factors.

The pump account includes the main pump, standby pump, motors, vauit, setting and installation, fittings, and labor costs.

Metering and Control

This account covers the cost of instrumentation, additional flow controllers, and sensors required to operate the distribution system. The metering and control account covers capital and installation costs, and is calculated to one percent of the piping system capital cost.

Building and Land Use

This account covers the expense of purchase or lease of land and the construction or modification of a building to house the system's instrumentation and control equipment. The costs are calculated to one percent of the piping system capital cost. 
Building Retrofit

The user can specify retrofit costs for buildings in each district type in order to study total costs of district heating in old built-up areas. The user specifies the retrofit cost per building in input data. The retrofit account will consist of retrofit costs for all of the buildings in the distribution system.

Storage

Water can be stored in vertical tanks at the terminus of the transmission line. The tanks are assumed to be vertical painted and insulated steel tanks.

The storage account includes material cost, field erection, handling and setting, piping, concrete, instrumentation, insulation, painting, and indirect costs.

Heat Pump

Several possible configurations using heat pumps and a water circulation system are possible (see discussion in section on "Special Options and Capabilities"). Due to the wide range in heat pump capital costs and rapidly evolving technology, a capital cost model for heat pumps is not used. The user should input the heat pump capital cost including installation, instrumentation, and indirect costs.

Heat Exchanger

If the heat exchanger option is specified, a tube and shell heat exchanger is designed to satisfy the input requirements and is located at the geothermal reservoir, even though the costs appear in the distribution system account.

The heat exchanger account includes material, installation, and indirect costs.

Engineering and Administration

This account is $12 \%$ of the piping system total cost to cover the engineering and administration costs of building the distribution system. 
OPERATING COST MODELS

The operating cost accounts consist of annual expenses and taxes. Meter reader and operating costs are related to the number of meters connected in the system. Maintenance cost is proportional to the capital investment and is based on estimates from water distribution systems. The pump operating, heat pump, supplemental heat, and heat exchanger costs are derived from models which are controlled by the system design. The other accounts (interest, taxes, capital replacement and insurance) are percentages of capital investment or portions of annual revenue. The percentages are specified through input data (see discussion in the section on "Capital and Operating Costs").

\section{Operating}

This account includes the personnel cost for operating the distribution system and administrative functions. The charges to this account depend on the number of meters connected to the system.

Maintenance

The maintenance account includes routine repair and maintenance of the distribution system. The charges depend on the pump size, the number of buildings connected, and the flow to each building.

Pump Operation

This account includes charges for the annual pumping costs, calculated from the input values for the cost of electricity, and pump and motor efficiencies. .

\section{Meter Readers}

This account includes wages, benefits, and overhead for meter readers with an assumed productivity of 50 meters/day. Heat Pump Operation

This account includes the electrical cost of operating the heat pump or heat pumps if they are used. The cost depends on the climatic data, the input values for the coefficient of performance and the cost of electricity. 
Supplemental Heat

The difference in heat demand at design temperature and the minimum temperature is met by purchasing heat and elevating the temperature of the circulating water. The charges to this account depend on the climatic data, the design temperature, and input value for the cost of supplemental heat.

Heat Exchanger

The annual operating cost of the heat exchanger is assumed to be $2 \%$ of the total capital cost of the heat exchanger.

Other Operating Cost Accounts

The following accounts are calculated as percentages of other accounts. The percentages are specified in the input data.

- Interim Capital Replacement - percent of total system capital cost

- Bond Interest - percent rate, charges assume compound interest on unpaid portion of debt and are calculated for each year

- Gross Revenue Tax - percent of annual revenue

- State Income Tax - percentage of taxable income (revenue less operating expenses including capital costs, energy costs, operating costs, interim capital replacement, property tax and insurance, interest and depreciation)

- Federal Income Tax - percentage of taxable income less state income tax

- Property Tax and Insurance - percentage of distribution system capital cost

\section{COST MODEL EOUATIONS}

Capital cost models are summarized in Table A-1, and operating cost models are summarized in Table A-2. The cost models use the equational form:

$$
\text { Cost }=a+b(x)(s)(t)
$$

Equation coefficients reflect fixed costs (a), variable costs (b), and scale size $(s)$ and $(t)$. Costs are in July 1976 dollars. Where cost equations are not appropriate, cost tables (Tables A-3 through A-6) are used. Cost data was gathered from three sources: industry vendors, mechanical contractors, and architect-engineers. 
TABLE A-1. District Heating System Capital Cost Coefficients (July 1976 Dollars) (NOTE: All measurements are in meter units) [Cost $\left.=a+b(x)^{s t}\right]$

Account No.

1.0

.0

$1_{1}^{1}$

\author{
Unit
}

Pipe

Carbon Steel Pipe

FRP Pipe

(fiberglass reinforced plastic)

\section{Insulation}

Calcium silicate

Fiberglass

Rigid Polyurethane (See Note 1)

Foam-in-Place Polyurethane

Fitting Insulation

Valve Insulation

- Nom. pipe size $\leq 0.0635$

- Nom. pipe size < 0.0635

Meter

Each

Each

Each
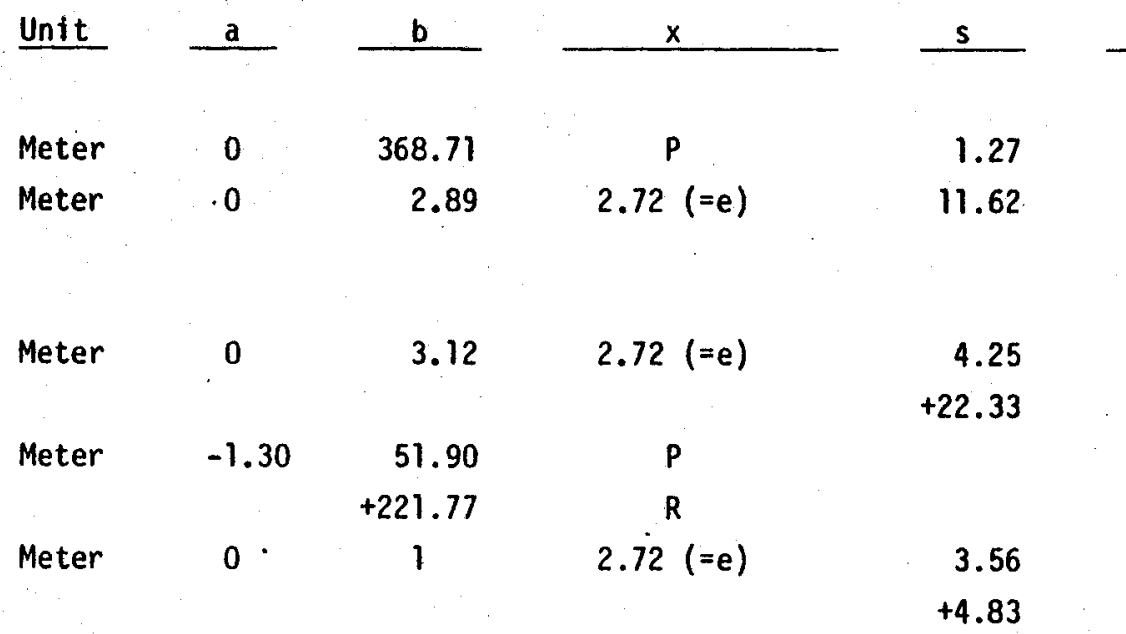

0

0

141.00

$(Q)(P)+(Q)(R)(2)$

0.91 $-(Y)(P)^{2}(0.79)$

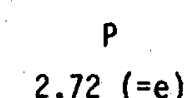

1.27

11.62

$2.72(=e)$

4.25

$+22.33$

$P$

$2.72(=e)$

3.56

$+4.83$

$+1.00$

$P$

$\ln (R)$

NOTE: (1) If nominal pipe diameter $=0.0254$ meters and pipe material $=$ carbon steel - Add $\$ 3.50 /$ meter to pipe cost. If nominal pipe diameter $=0.0381$ meters and pipe material = carbon steel - Add $\$ 1.70 /$ meter to pipe cost.

$F=$ Insulated Cost/Meter $\quad P=$ Pipe. Diameter

$Q=$ Outside Diameter of Pipe \& Insulation

$R=$ Insulation Thickness

$Y=$ ilumber of Pipes in Conduit 
TABLE A-1. (contd)

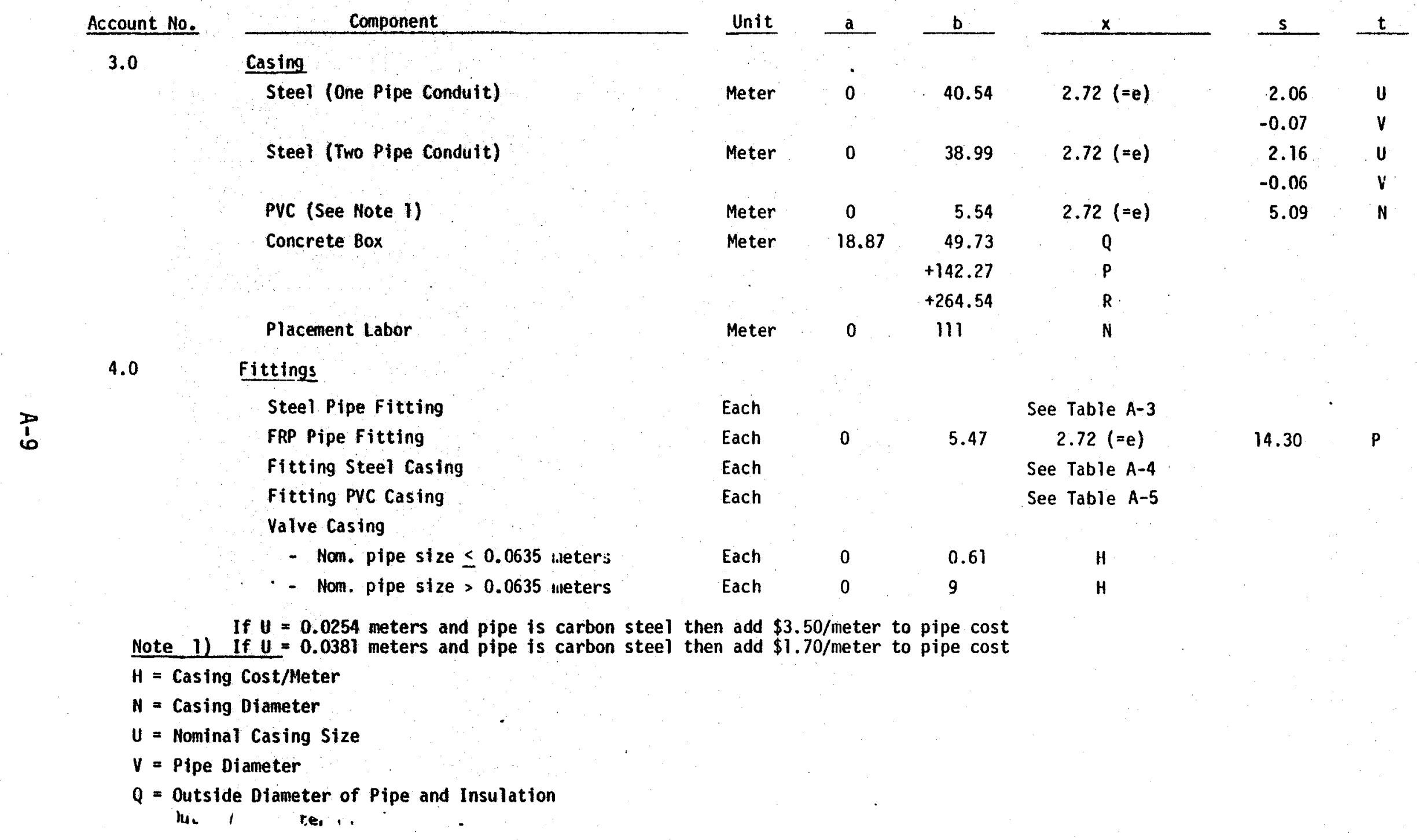


TABLE A-1. (contd)

\begin{tabular}{|c|c|c|c|c|c|c|c|}
\hline Account No. & Component & Unit & a & b & $x$ & $\underline{s}$ & $\mathbf{t}$ \\
\hline \multirow[t]{8}{*}{5.0} & Expansion Loop & & & & & & \\
\hline & Expansion loop (See Note 2) & Each & & & $(C)(D)$ & & \\
\hline & & & & & $+(4)(E)$ & & \\
\hline & & & & & $+(C)(F)$ & & \\
\hline & & & & & $+(4)(G)$ & & \\
\hline & & & & & $+(C)(H)$ & & \\
\hline & & & & & $+(4)(J)$ & & \\
\hline & & & & & $+(c)(k)$ & & \\
\hline \multirow[t]{14}{*}{6.0} & Trenching Labor & & & & & & \\
\hline & Trenching & & & & & & \\
\hline & - Two conduit (Pipe opt. 4) & Meter & 0.95 & 12.77 & N & 2.0 & 1 \\
\hline & & & & +11.75 & N & & \\
\hline & - Two conduit (Pipe opt. 5) & Meter & 0.98 & 6.19 & N & 2.0 & 1 \\
\hline & & & & +0.19 & N & & \\
\hline & & & & +2.38 & $\mathbf{P}$ & & \\
\hline & & & & -12.47 & $P$ & 2.0 & 1 \\
\hline & $\cdot \cdot$ & & & +18.66 & $(N)(P)$ & & \\
\hline & - One conduit (Pipe otp. $1,2,3,6$ ) & Meter & 0.61 & 6.19 & $N$ & 2.0 & 1 \\
\hline & & & & +6.79 & N & & \\
\hline & - Concrete box conduit & Meter & 0.92 & 2.97 & $Q$ & 2.0 & 1 \\
\hline & & & & +3.98 & ? & & \\
\hline & & & & +0.27 & $\mathbf{R}$ & & \\
\hline
\end{tabular}

NOTE: (2) Expansion loop length $=(19.27)$ (nom. pipe dia.) $)^{0.46}-(9)$ (nom. pipe dia.)

$C=$ Expansion loop length $D=$ Pipe cost/meter $H=$ Casing Cost/Meter $\cdot \mathrm{J}=$ Casing fitting cost $Q=$ Outside Diameter of Pipe and Insulation
$E=$ Pipe fitting cost $F=$ Insulated Cost $/$ Meter

$K=$ Trenching cost/meter $N=$ Casing Diameter $P=$ Pipe Diameter

fitting cost

$R=$ Insulation Thickness 
TABLE A-1. (contd)

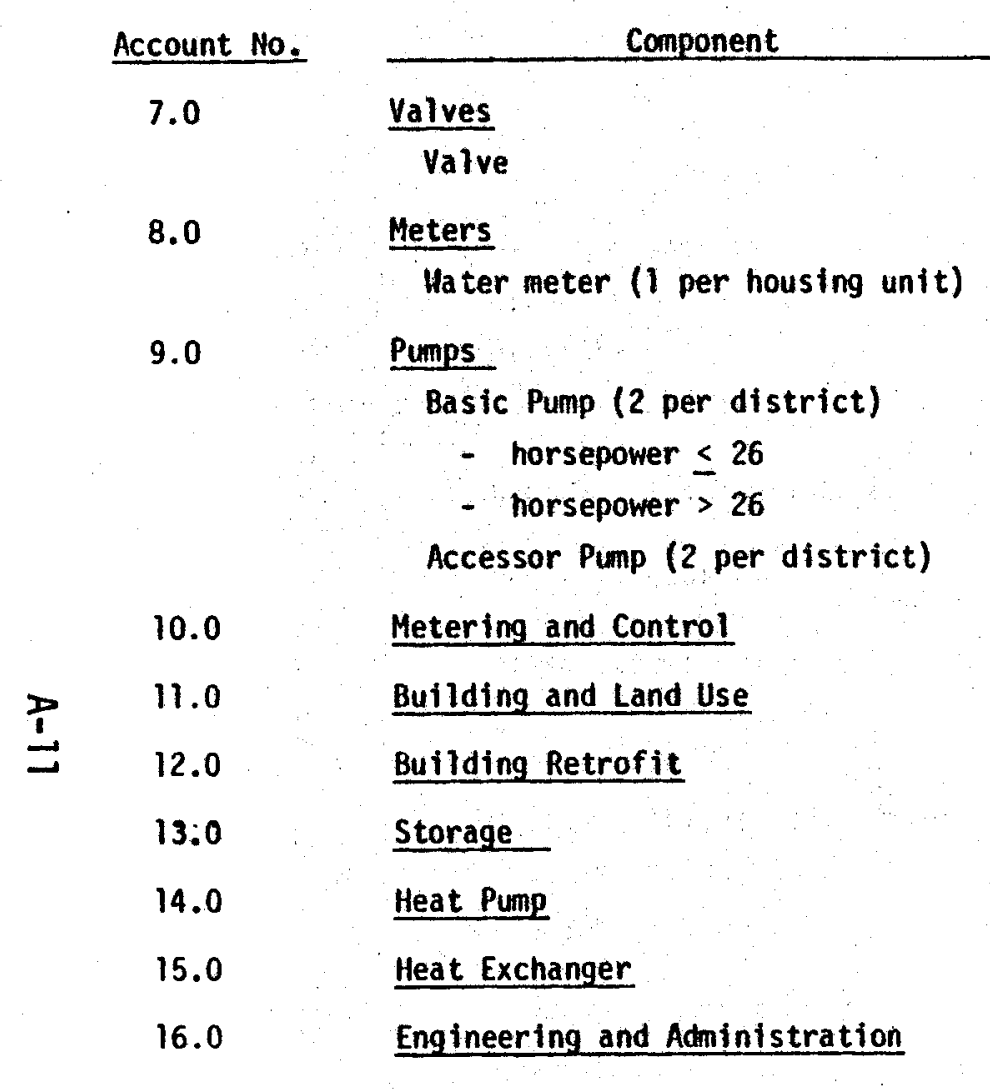

$M=$ Horsepower $\quad C T=$ Piping System Capital Cost

GL = Storage Capacity in Gallons

93.3

\begin{tabular}{lrr} 
Each & 1269 & \multicolumn{1}{c}{80} \\
Each & 4929 & \multicolumn{1}{l}{64} \\
Each & 0 & 81.53 \\
& 0 & .01 \\
& 0 & .01 \\
& \\
& Input
\end{tabular}

See Table A-4

See Table A-6

Input

NB = Number of Bulldings Connected to the System

$\mathbf{P}=$ Pipe Diameter 
TABLE A-2. Operating Cost Models

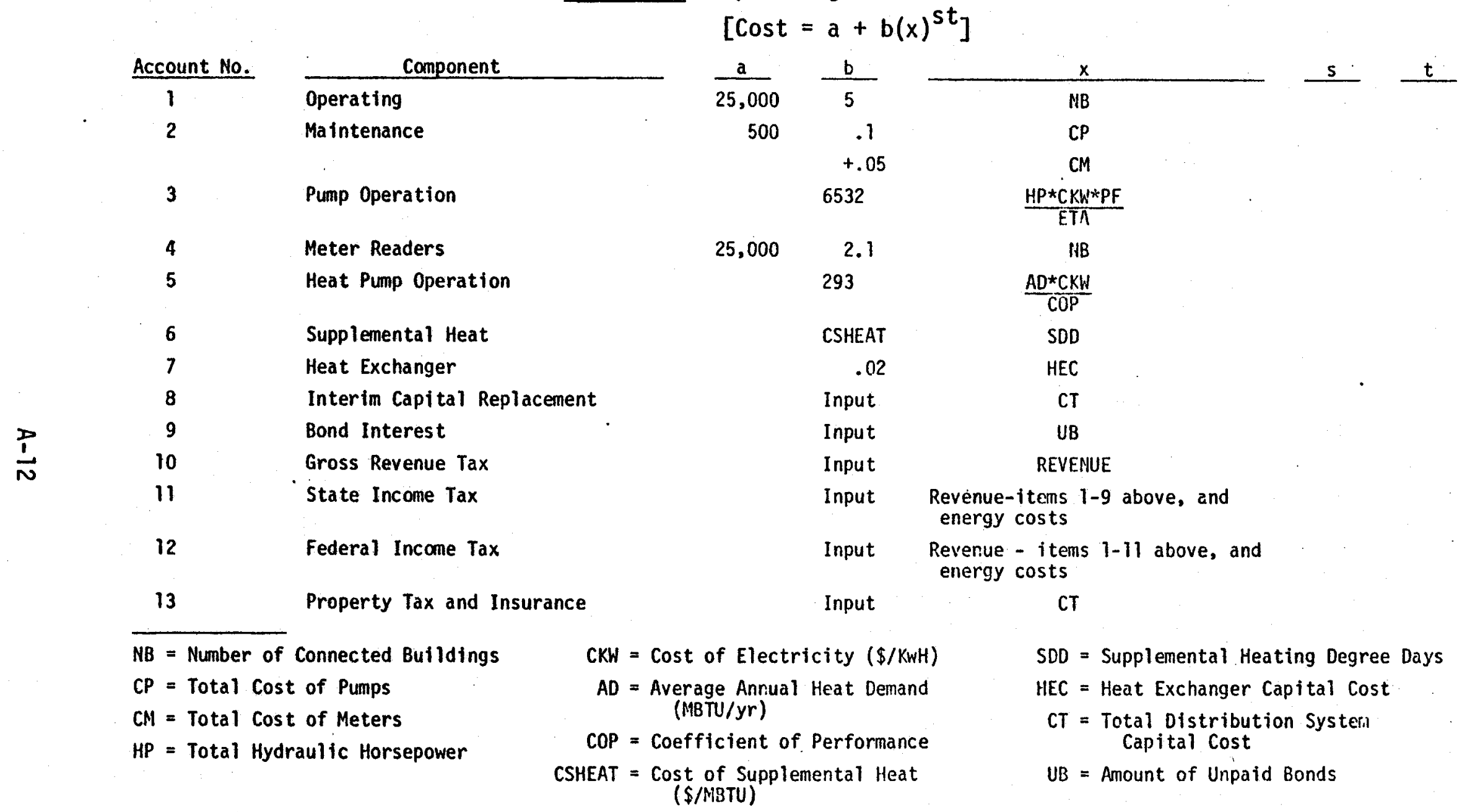


TABLE A-3. Valves and Carbon Steel Fitting

Nominal Pipe

Diameter (meters)

0.0254

0.0381

0.0508

0.0635

0.0762

0.1016

Cost/Fitting (\$)

0.1524

3

Cost/Vaive (\$)

0.2032

0.2540

3

58

3

70

4

85

5

118

9

274

375

24

528

41

776

0.3048

84

1276

109

1687

0.3556

162

2535

0.4064

227

3802

0.4572

322

5052

0.5080

433

6740

0.6096

638

9678 
TABLE A-4. Steel Casing Fitting

Nominal Inside Casing Diameter (meters)

0.1614

0.2122

0.2662

Cost/Fitting (\$)

0.3170

145

0.3488

0.3996

158

0.4504

295

0.5012

315

0.5489

340

0.5997

373

0.6505

406

0.6998

432

0.7506

436

0.8014

505

0.8522

550

0.9144

558 
TABLE A-5. PVC Casing Fitting

Nominal Inside

Casing Diameter (meters)

0.0762

0.1016

0.1143

0.1270

0.1524

0.1778

0.2032

0.2540

0.3048

0.3556

0.4064

0.4572

0.5080

0.6096
Cost/Fitting (\$)

27

27

35

40

40

57

76

108

143

190

247

437

591

828

TABLE A-6. Meter

Minimum Flow

(GPM)

0
7

30

50

100

160

360

500

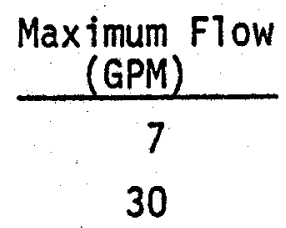

50

100

160

360

500

1000
Cost/Meter

\begin{tabular}{c}
$(\$)$ \\
\hline 164 \\
229 \\
333 \\
628 \\
941 \\
3111 \\
4766 \\
9639
\end{tabular}


Costs are factored to reflect lower unit costs for larger piping systems; such systems have reduced material unit costs because of quantity purchase discounts. Also the installation labor learning curve lowers unit labor costs for large systems. Costs are "factored" after they are generated from component cost models. Pipe, insulation, casing, expansion loop, and trenching labor costs are multiplied by FACTOR 1. Fitting, valve, and meter costs are multiplied by FACTOR 2. Table A-7 lists values for these factors.

\section{TABLE A-7. Cost Factors}

$\begin{array}{lcc}\text { Housing Units in District }> & 800 & \text { FACTOR } 2=0.6 \\ \text { Housing Units in District }>600 \text { and }<800 & \text { FACTOR } 2=0.75 \\ \text { Housing Units in District }>400 \text { and }<600 & \text { FACTOR 2 }=0.85 \\ \text { Housing Units in District }>200 \text { and }<400 & \text { FACTOR 2 }=0.95 \\ \text { Housing Units in District }< & 200 & \text { FACTOR } 2=1.00\end{array}$

Length of Same Diameter Pipe in District > $4000 \mathrm{~m} \quad$ FACTOR $1=0.85$

Length of Same Diameter Pipe in District $>2500 \mathrm{~m}$ and $<4000 \mathrm{~m}$ FACTOR $1=0.90$

Length of Same Diameter Pipe in District $>1000 \mathrm{~m}$ and $<2500 \mathrm{~m}$ FACTOR $1=0.95$

Length of Same Diameter Pipe in District $<\quad 1000 \mathrm{~m} \quad$ FACTOR $1=1.00$ 
APPENDIX B

DESCRIPTION OF PREDEFINED RESIDENTIAL DISTRICT TYPES FOR OPTIONAL USE IN THE GEOCITY MODEL 
APPENDIX B

DESCRIPTION OF PREDEFINED RESIDENTIAL DISTRICT TYPES

FOR OPTIONAL USE IN THE GEOCITY MODEL

Many residential areas in the United States can be described by one of five residential district types defined in the GEOCITY model data base. These district types are:

- Suburban

- High density single family

- Garden apartments

- Townhouses

- Highrise apartments

The district type parameters of peak heat demand, hot water demand, density, reject temperature and diversity factor have been calculated for each of these district types. The user may use these district types as defined or may modify one or more parameters as required.

Peak heat demand was calculated by designing typical residential units for each district type and calculating the heat loss according to ASHRAE procedures assuming $-5^{\circ} \mathrm{F}$ outside temperature, $67^{\circ} \mathrm{F}$ inside temperature and a $15 \mathrm{mph}$ wind. Floor plans, dimensions and construction parameters for each of these district types are summarized in Figures B-1 through B-5. Hot water demand is based on the number of residents in a typical building and ASHRAE design recommendations. Density data is an average of the values recommended in various planning books and zoning guides. The district type parameters used by GEOCOST are also summarized in Tables B-1 through B-5. 


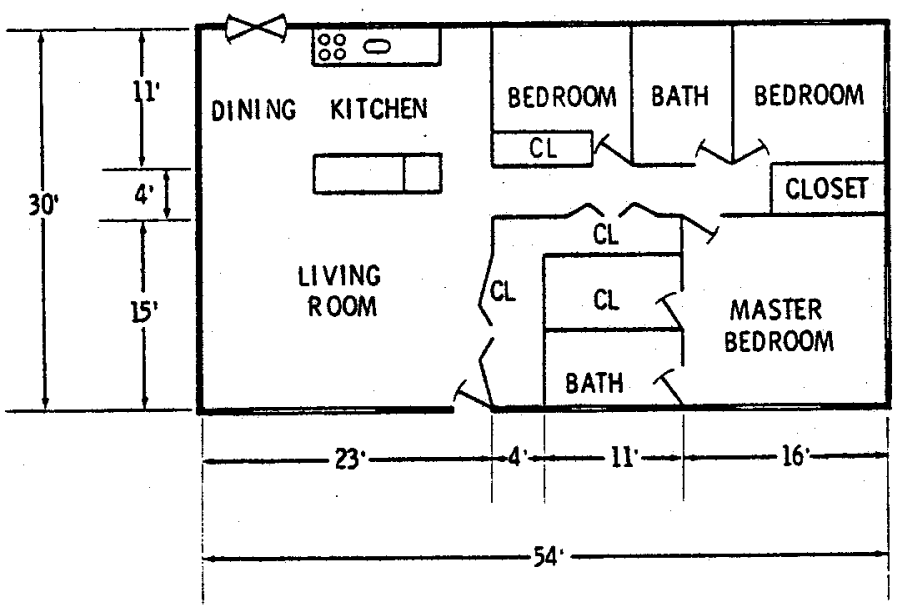

FIGURE B-1. Plan of Suburban Residential House $125 \times 30 \mathrm{ft}$. Attached garage not shown.

TABLE B-1. Design Basis for Suburban Residential House $125 \times 30 \mathrm{ft}$

SUBURBAN RESIDENTIAL

NUMBER OF STORIES - 1

DIMENSIONS

FLOOR it $^{2}$

EXTERIOR WALL AREA $\mathrm{ft}^{2}$

GARAGE WALL AREA $\mathrm{ft}^{2}$

1620

WINDOW GLASS it $^{2}$

918 (NET OF GLASS)

DOOR AREA $\mathrm{ft}^{2}$.

240

CEILING $\mathrm{ft}^{2}$

186

21

STORY HEIGHT $\mathrm{It}^{2}$

1620

8

CONSTRUCTION PARAMETERS

RLOR

MAPLE FINISH FLOORING ON YELLOW PINE SUEFLOORING.

EXTERIOR WALLS

BRICK VENEER, BUILDING PAPER, WOOD SHEATHING, STUDDING, METAL LATH, 2 in. INSULATION

CEILING METAL LATH AND PLASTER, 6 in. INSULATION

WINDOWS DOUBLE-HUNG WOOD WINDOWS

\section{DISTRICT TYPE PARAMETERS}

PEAK HEAT DEMAND

HOT WATER DEMAND

DENSITY

REJECT TEMPERATURE

DIVERSITY FACTOR
53,000 BTU $/ \mathrm{hr}$

60 gallons/day

2560 HOUSESI SQ. MILES

$1000^{\circ}$

0.7 


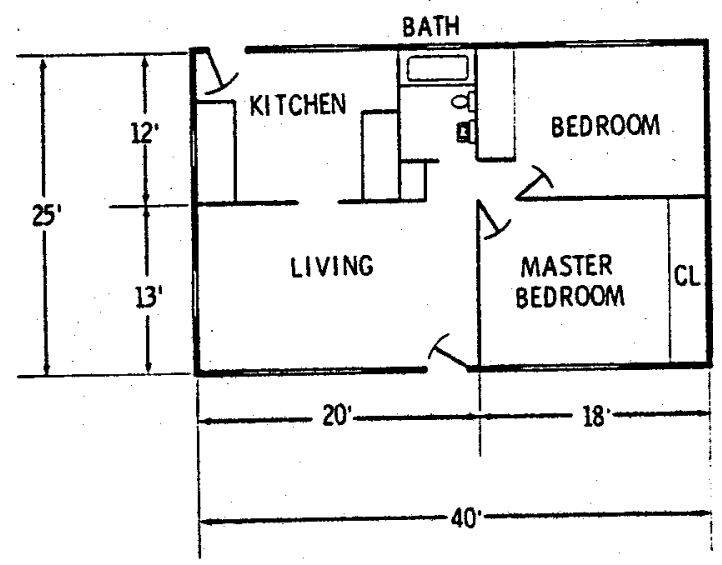

FIGURE B-2. Plan for High Density Single Family Home

TABLE B-2. Design Basis for High Density Single Family Home

HIGH DENSITY

NUMBER OF STORIES 1

DIMENSIONS

$\begin{array}{lr}\text { FLOOR } \cdot \mathrm{ft}^{2} & 1000 \\ \text { EXTERIOR WALLS } \mathrm{ft}^{2} & 865 \\ \text { WINDOW } \mathrm{ft}^{2} & 133 \\ \text { DOOR } \mathrm{ft}^{2} & 42 \\ \text { CEILING } \mathrm{ft}^{2} & 1000 \\ \text { STORY HEIGHT } \mathrm{ft} & 8\end{array}$

CONSTRUCTION PARAMETERS

FLOOR

EXTERIOR WALLS

MAPIE FINISH FLOORING ON YELLOW

PINE SUBFLOORING

BRICK VENEER, BUILDING PAPER,

WOOO SHEATHING, STUDOING.

METAL LATH, 2 In. INSULATION

CEILING METAL LATH AND PLASTER, 6 in.

INSULATION

WINDOWS

DOUBLE-HUNG WOOD WINDOWS

DISTRICT TYPE PARAMETERS

PEAK HEAT DEMAND

34,000 BTU/hr

HOT WATER DEMAND

55 gallons / day

DENSITY

4,480 HOU SES I SQ. MILE

REJECT TEMPERATURE

$100^{\circ} \mathrm{F}$

DIVERSITY FACTOR

0.7 


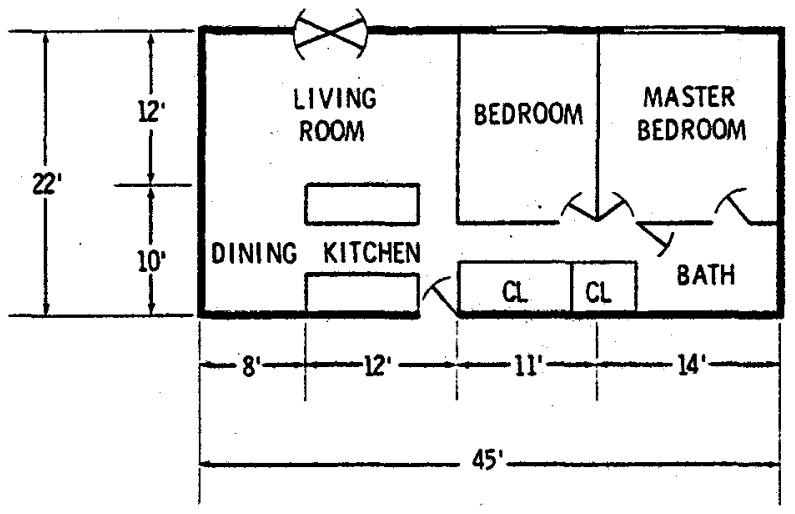

FIGURE B-3. Plan for Garden Apartment Unit

TABLE B-3. Design Basis for Garden Apartment Unit GARDEN APARTMENT

NUMBER OF STORIES - EACH APARTMENT IS ONE STORY AND -

IS CONTAINED IN A 2 STORY BUILDING

DIMENSIONS

FLOOR it $^{2}$

EXTERIOR WALLS $\mathrm{ft}^{2} \quad 617$

WINDOWS $\mathrm{ft}^{2}$

DOOR $\mathrm{ft}^{2} \quad 21$

CEILING IR (990) FOR HEATLOSS

STORY HEIGHT $\mathrm{It}$

CONSTRUCTION PARAMETERS

FLOOR

MAPLE FINISH FLOORING ON YELLOW

PINE SUBFLOORING

EXTERIOR WALLS

BRICK VENEER, BUILDING PAPER,

WOOD SHEATHING, STUDDING,

METAL LATH, 2 in. INSULATION

CEILING

METAL LATH AND PLASTER 6 in. INSULATION

WINDOWS

DOUBLE-HUNG WOOD WINDOWS

DISTRICT TYPE PARAMETERS

PEAK HEAT DEMAND

$1.38 \mathrm{MBTU} / \mathrm{hr}$

HOT WATER DEMAND

3030 gallons/day

DENSITY

REJECT TEMPERATURE

293 BUILDINGS/SQ. MILE

$100^{\circ} \mathrm{F}$

DIVERSITY FACTOR

0.7 


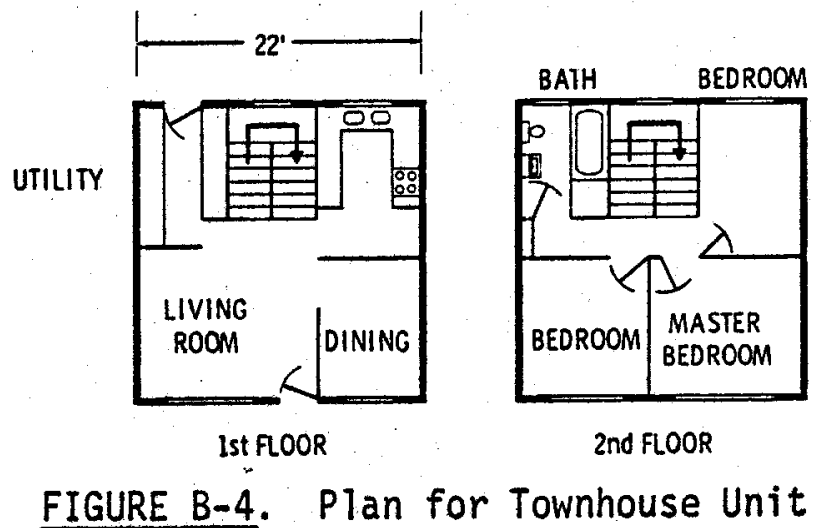

TABLE B-4. Design Basis for Townhouse Unit

ROW HOUSE

NUMBER OF STORIES - 2

DIMENSIONS

FLOOR $\mathrm{ft}^{2}$

FLOOR $\mathrm{ft}^{2}$

506 (1st STORY)

EXTERIOR WALL $\mathrm{ft}^{2}$

506 (2nd STORY)

WINDOW $\mathrm{ft}^{2}$

582

124

DOOR $\mathrm{ft}^{2}$

CEILING $\mathrm{ft}^{2}$

STORY HEIGHT it

21

506

8

CONSTRUCTION PARAMETERS

FLOOR

MAPLE FINISH FLOORING ON YELLOW PINE SUBFLOORING

EXTERIOR WALLS

BRICK VENEER, BUILDING PAPER, WOOD SHEATHING, STUDOING. METAL LATH, 2 In. INSULATION

CEILING

WINDOWS

METAL LATH AND PLASTER, 6 in. INSULATION

DOUBLE-HUNG WOOD WINDOWS

DI STRICT TYPE PARAMETERS

PEAK HEAT DEMAND

0.9 MBTuthr

HOT WATER DEMAND

B15 gallons/day

DENSITY

373 BUILOINGS / SQ. MILE

REJECT TEMPERATURE

$100^{\circ} \mathrm{F}$

DIVERSITY FACTOR

0.7 


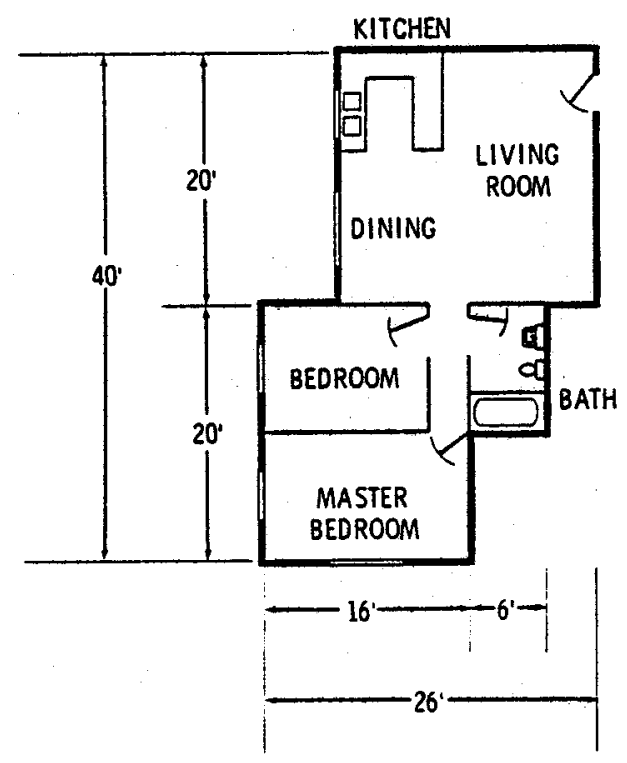

FIGURE B-5. Plan for High Rise Apartment Unit Eight Apartments per Floor

TABLE B-5. Design Basis for High Rise Apartment Unit

HIGH RISE APARTMENT

\begin{tabular}{|c|c|}
\hline NUMBER OF STORIES - & $\begin{array}{l}\text { EACH APARTMENT IS ONE STORY } \\
\text { AND IS CONTAINED IN A9 STORY } \\
\text { BUILDING. }\end{array}$ \\
\hline \multicolumn{2}{|l|}{ DIMENSIONS } \\
\hline FLOOR $\mathrm{ft}^{2}$ & 780 \\
\hline EXTERIOR WALL $\mathrm{ft}^{2}$ & 370 \\
\hline WINDOWS $\mathrm{H}^{2}$ & 78 \\
\hline DOOR $\mathrm{ft}^{2}$ & 21 \\
\hline$R O O F \mathrm{t}^{2}$ & I/9 (780) FOR HEAT LOSS \\
\hline STORY HEIGHT $\mathrm{ft}$ & 8 \\
\hline \multicolumn{2}{|l|}{ CONSTRUCTION PARAMETERS } \\
\hline EXTERIOR WALLS & $\begin{array}{l}\text { BRICX VENEER, BUILDING PAPER, WOOD } \\
\text { SHEATHING, STUDDING, METAL LATH, } \\
2 \text { IN. INSULATION }\end{array}$ \\
\hline CEILING & $\begin{array}{l}\text { METAL LATH ANO PLASTER, } 6 \text { in. } \\
\text { INSULATION }\end{array}$ \\
\hline WINDOWS & DOUBLE-HUNG WOOD WINDOWS \\
\hline \multicolumn{2}{|l|}{ DI STRICI TYPE PARAMETERS } \\
\hline PEAK HEAT DEMAND & 1.73 MBTU/hr \\
\hline HOT WATER OEMAND & 5400 gallons / đay \\
\hline DENSITY & 385 BUILDINGSISQ. MILES \\
\hline REJECT TEMPERATURE & $100^{\circ} \mathrm{F}$ \\
\hline DIVERSITY FACTOR & 0.7 \\
\hline
\end{tabular}


APPENDIX C

EXAMPLE PRINTOUT FROM GEOCITY 
APPENDIX C

\section{EXAMPLE PRINTOUT FROM GEOCITY}

An example summary printout from the GEOCITY code for a city consisting of six districts with a two-pipe distribution system is shown in the following pages. More detailed output of the fluid transmission system is available at the user's option. Detalled printout for only one of the six districts is included.

The first page lists the characteristics of the districts comprising the city. All values are input or derived directly from the input data. The detailed description of the piping network including pipe size, flow rate, and fluid conditions is shown on page $\mathrm{C}-4$. The detailed material requirement and capital costs for the distribution system of this district is on page $c-5$. The detailed printouts for districts 2 through 6 are not included, since they have format as for district 1. A description of the system's mains connecting the districts to the transmission line is shown on page $C-6$. On page $\mathrm{C}-7$ the material requirement and capital and operating costs for all of the districts are summarized. Description of the climate, summary of heat demands, fluid demands, and capital costs are shown on page C-8.

Output from the reservoir model begins on page $\mathrm{C}-9$ which summarizes the input characteristics of the reservoir and wells. The direct expenses associated with reservoir exploration, reservoir development, and reservoir operation are shown on page $\mathrm{C}-10$. Other significant input economic factors for the reservoir and case identification information are 1isted on page $\mathrm{C}-11$. Annual cash flow data for the major reservoir expenses are shown on page C12. Summary accounts of deductible expenses are contained on page C-13. A simplified income statement is shown on page $\mathrm{C}-14$ and the net cash flow and investment position is shown on page $\mathrm{C}-15$. Page $\mathrm{C}-16$ contains a summary of the costs of energy for the reservoir. In the right-hand column labeled distribution of energy costs, the taxes, royalty payments, and bond interest have been real10cated to the direct cost components for the reservoir. The rate of return on 
investment is included in the distributed energy cost for each component. The deductible nature of bond interest causes this expense to be partially included in the rate of return (the part which is included in the present worth factor) and the remainder to be accounted for separately. This completes the reservoir model.

Costs associated with the distribution system begin on page $\mathrm{C}-17$ with the capital costs and summary of the economic input data. Pages $\mathrm{C}-18$ to $\mathrm{C}-21$, contain the same economic and accounting information for the distribution system as pages $\mathrm{C}-12$ to $\mathrm{C}-15$ for the reservoir. A summary of the total costs for the distribution system are shown on page $C-22$. All costs from the reservoir are included in the energy supply cost item. The energy supply costs are derived from the energy cost account shown on page $\mathrm{C}-18$. This energy cost account is identical to the total power sales from the reservoir. As for the reservoir cost distribution, the taxes and bond interest have been reallocated to the primary cost components in the righthand columns of the cost distribution. 
SAMPLE niHPUT FAOM GEORITY

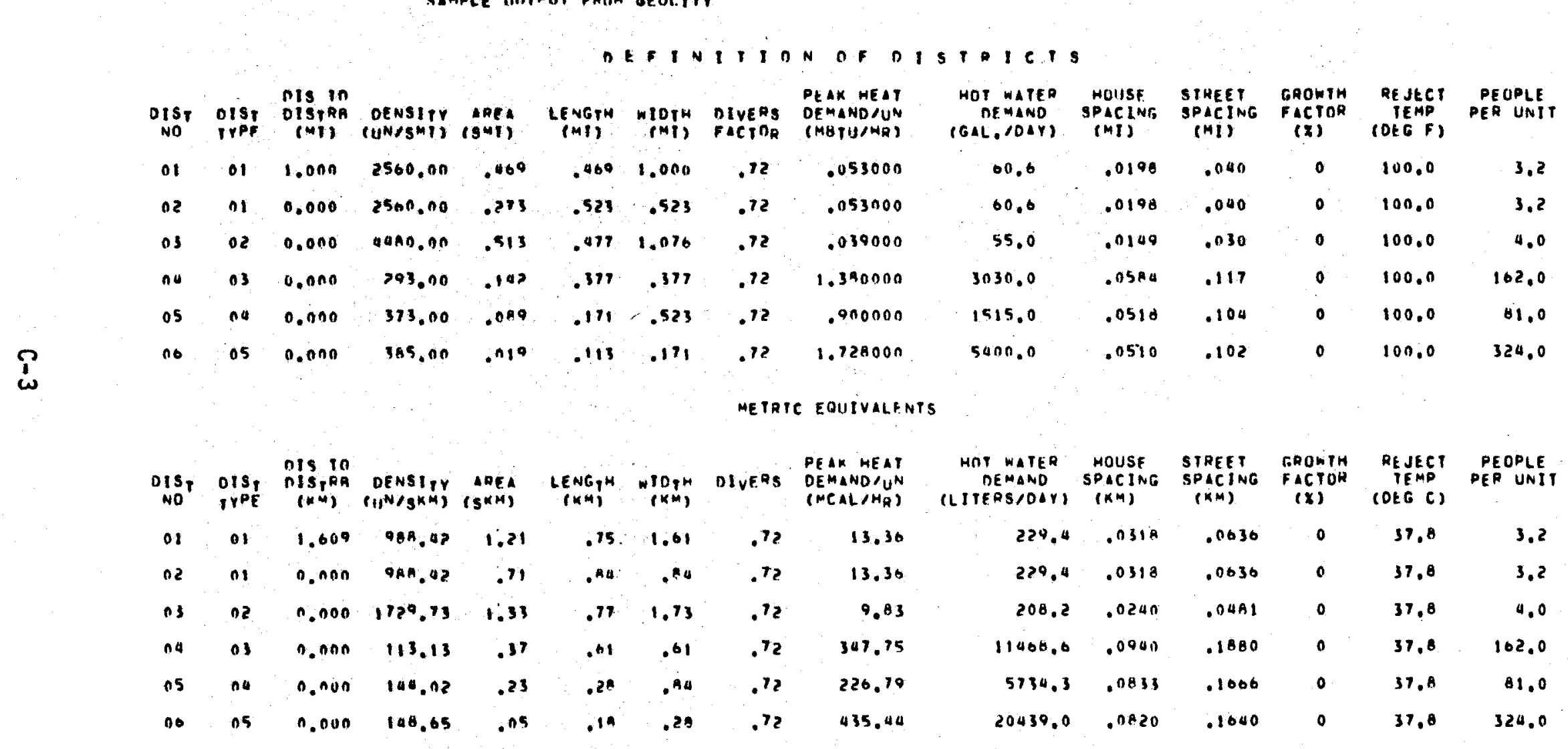


SAMPLE OIITPUT FROM GEOCITY

DISTRIAUTION SYSIEM OF DISTRIPT I TAR PIPE SYSTEM

HOUSE OESCRIPTITN

\begin{tabular}{|c|c|c|c|c|c|c|}
\hline $\begin{array}{l}\text { FLOWAEIE } \\
\text { (LR/SEC) }\end{array}$ & $\begin{array}{l}\text { HEAT LUSS } \\
\text { (ATULSERE) }\end{array}$ & $\begin{array}{l}\text { IEMPES } \\
\text { SUPPL }\end{array}$ & $\begin{array}{l}\text { TURE (E) } \\
\text { RE TURN }\end{array}$ & $\begin{array}{l}\text { MEAD LOSS } \\
\text { FEEY }\end{array}$ & $\begin{array}{l}\text { NOMINAL } \\
\operatorname{DTAM}(I N)\end{array}$ & $\begin{array}{l}\text { INSUL } \\
\text { (IN) }\end{array}$ \\
\hline .2 &.,- 2 & $20 \mathrm{~A}$. & lon. & 3.84 & 1.00 & 1.5 \\
\hline
\end{tabular}

STREET DESCRIPIION

STREET HOIISE
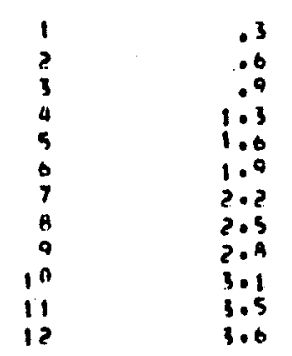

$-3.4$

-3.4
-3.4

$-3.4$

$-3.4$

$-3.0$

$-3.4$

$-4.9$

-4.0
-4.0

-4.0
0.0

3.84

1.00

1.5

\begin{tabular}{|c|c|c|c|}
\hline 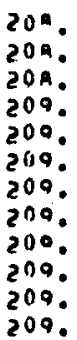 & 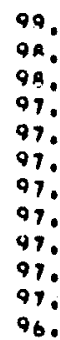 & $\begin{array}{r}.62 \\
2.22 \\
4.68 \\
7.94 \\
11.07 \\
16.75 \\
22.24 \\
3.08 \\
4.57 \\
5.55 \\
0.62 \\
0.00\end{array}$ & $\begin{array}{l}1.00 \\
1.00 \\
1.00 \\
1.00 \\
1.00 \\
1.00 \\
1.00 \\
1.50 \\
1.50 \\
1.50 \\
1.50 \\
1.50\end{array}$ \\
\hline
\end{tabular}

LATERIL DESCRIOTIOM LATEAL STREET

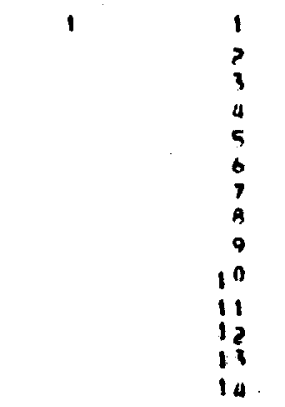

.2
5.4
10.7
15.9
21.1
30.3
31.5
30.7
42.0
47.2
52.4
57.0
62.8
00.0

$-7.4$

200.
2100
210.

$210 \cdot$

(2)

210

210.

210.

10.

$210^{\circ}$

210.

21 .

$-16.1$

62.9

$-16.1$

210.

210.

130.1
9
9
0
0
0
9
4
4
9
0
9
9
0
0
0
0
0
0

.03

9.73
12.65

0.79

11.45

4.80
0.69

8.87

11.32

140.5

2.43

3.030
3.03

2.22

91.09
1.50

2.110

2.50

3.00

3.00

$4.00 \quad 3.0$

$4.00 \quad 3.0$

$4.00 \quad 3.0$

$0.00 \quad 3.0$

$6.00 \quad 3.0$

$\begin{array}{ll}6.00 & 3.0 \\ 6.00 & 3.0\end{array}$

$0.00 \quad 2.0$

$8.00 \quad 3.5$ 
Bample outout FRan GeOCtit

DISTRICT I CAPITAL COSTS IND MATERIAL KFBUIAEMENTS

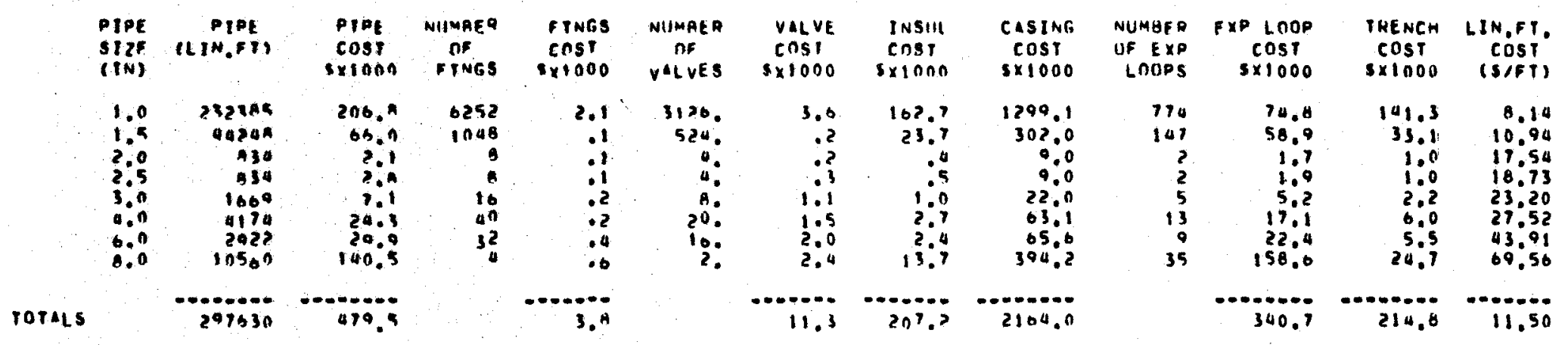

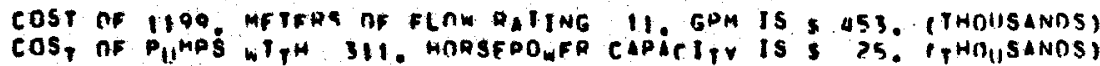

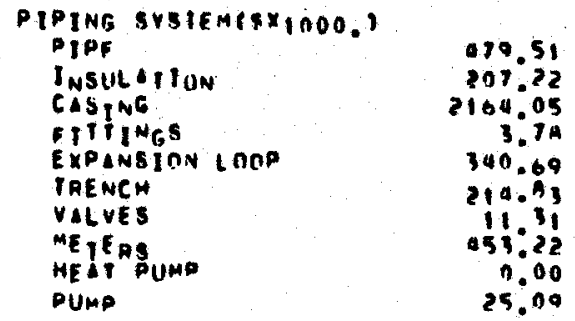

TOTAL SYSTEM CADITAL COST 3A99.10 
SAMPLE OUTPUY FROM GENCIIY

DESCAIPTION OF MAINS SERVING THE DISTRICTS

\begin{tabular}{|c|c|c|c|c|c|c|c|c|c|}
\hline & & $\begin{array}{l}\text { FI OWRATE } \\
\text { (LASSEC) }\end{array}$ & $\begin{array}{l}\text { HFAT LOSS } \\
\text { PATU/SEC) }\end{array}$ & $\begin{array}{l}\text { TEMPER, } \\
\text { SUPPLY }\end{array}$ & $\begin{array}{l}\text { TIIRE (F) } \\
\text { QETIIRN }\end{array}$ & $\begin{array}{l}\text { MEAD LOSS } \\
\text { FEET }\end{array}$ & $\begin{array}{l}\text { NOMINAL } \\
\text { DILM(IN) }\end{array}$ & $\begin{array}{l}\text { INSUL } \\
\text { (IN) }\end{array}$ & $\begin{array}{c}\text { CUMULATIVE } \\
\text { FLOWRAIE } \\
\text { (LB/SEC) }\end{array}$ \\
\hline $\begin{array}{c}\text { MAYN } \\
\text { NUMBER }\end{array}$ & $\begin{array}{l}\text { DISTRICT } \\
\text { NUMBEA }\end{array}$ & & & & & & & & \\
\hline 1 & 1 & 136.1 & .492 .6 & 210. & 03. & 81.69 & 8.00 & 3.5 & 136.1 \\
\hline 2 & 2 & 79.4 & 0.0 & 210. & 96. & 0.00 & 4.00 & 3.5 & 79.4 \\
\hline 3 & 3 & 196.7 & 0.0 & 210. & 94. & 0.00 & 0.00 & 3.5 & 196.7 \\
\hline 4 & $\Delta$ & 136.3 & 0.0 & 210 & 90. & 0.00 & 4.00 & 3.5 & 136.3 \\
\hline 5 & 5 & 68,8 & 0.0 & 210. & ๑. & 0.00 & 4.00 & 3.5 & 68.8 \\
\hline 6 & 6 & 34.1 & 0.0 & 210. & 100. & 0,00 & 3.00 & 3.5 & 35.1 \\
\hline
\end{tabular}


SAMPLE DIIPIIT GROM GEOCIIY

IOTAL CAPITAL COSTS AND MATERIAL REOHIREMENTS

\begin{tabular}{|c|c|c|c|c|c|c|c|c|c|c|c|c|}
\hline $\begin{array}{l}\text { PIPE } \\
\text { SIIE } \\
\text { IINI }\end{array}$ & $\begin{array}{l}\text { PIPE } \\
\text { (LIN.tII }\end{array}$ & $\begin{array}{l}\text { PIPF } \\
\text { rost } \\
\text { sxiono }\end{array}$ & $\begin{array}{l}\text { NIIMAEA } \\
\text { OF } \\
\text { FINGS }\end{array}$ & $\begin{array}{l}\text { FINGS } \\
\text { CNS } \\
\text { Sxio0o }\end{array}$ & $\begin{array}{l}\text { NUMAER } \\
\text { OF } \\
\text { VAl VES }\end{array}$ & $\begin{array}{l}\text { Valve } \\
\text { cost } \\
\times 1000\end{array}$ & $\begin{array}{l}\text { INSIIL } \\
\text { Cost } \\
\text { S } 1000\end{array}$ & $\begin{array}{c}\text { COSING } \\
\text { COST } \\
\text { SX1000 }\end{array}$ & $\begin{array}{l}\text { NUMGEA } \\
\text { OF EXP } \\
\text { LOOPS }\end{array}$ & $\begin{array}{l}\text { EXP LOOP } \\
\text { Enst } \\
\text { Sx1000 }\end{array}$ & $\begin{array}{l}\text { IAENCH } \\
\text { COST } \\
S \times 1000\end{array}$ & $\begin{array}{c}\text { WN,FT } \\
\text { COST } \\
\text { (STET) }\end{array}$ \\
\hline $\begin{array}{l}1.0 \\
1.5 \\
2.0 \\
2.5 \\
3.0 \\
0.0 \\
0.0 \\
0.0\end{array}$ & 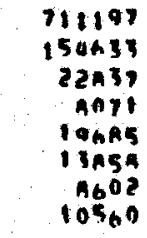 & $\begin{array}{r}631.9 \\
232.8 \\
51.5 \\
26.5 \\
79.5 \\
63.5 \\
65.2 \\
100.5\end{array}$ & $\begin{array}{r}22072 \\
3260 \\
136 \\
64 \\
164 \\
148 \\
116\end{array}$ & $\begin{array}{r}6.5 \\
11.0 \\
1.5 \\
1.5 \\
1.5 \\
.8 \\
.6\end{array}$ & $\begin{array}{r}11036 . \\
1634 . \\
368 . \\
32 . \\
72 . \\
74 . \\
58 . \\
2 .\end{array}$ & $\begin{array}{r}11.0 \\
18.3 \\
.9 \\
2.9 \\
9.7 \\
10.0 \\
4.0 \\
2.0\end{array}$ & $\begin{array}{r}503.7 \\
84.6 \\
9.7 \\
4.45 \\
11.5 \\
10.4 \\
7.2 \\
13.7\end{array}$ & $\begin{array}{r}3975.8 \\
1080.9 \\
189.4 \\
44.7 \\
252.0 \\
232.0 \\
189.7 \\
394.2\end{array}$ & $\begin{array}{r}2370 \\
515 \\
70 \\
26 \\
65 \\
46 \\
28 \\
35\end{array}$ & $\begin{array}{r}233.1 \\
105.8 \\
38.9 \\
14.1 \\
59.1 \\
63.2 \\
64.7 \\
158.0\end{array}$ & $\begin{array}{r}432.5 \\
118.3 \\
20.5 \\
9.0 \\
25.2 \\
21.7 \\
15.9 \\
24.7\end{array}$ & $\begin{array}{l}8.15 \\
11.06 \\
13.52 \\
18.17 \\
22.02 \\
30.53 \\
42.74 \\
69.59\end{array}$ \\
\hline
\end{tabular}

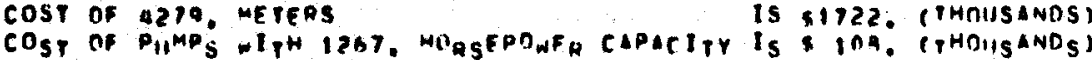

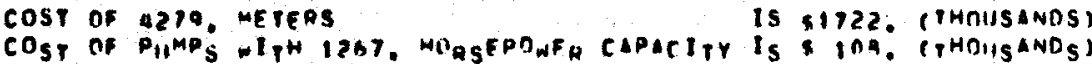

Cepital cost accounts $(9 \times 1000$.

\begin{tabular}{|c|c|}
\hline $\begin{array}{l}\text { PIPE } \\
\text { INSULATION } \\
\text { CASING } \\
\text { IITIINGS } \\
\text { EYPINSION LOND } \\
\text { IRENEA } \\
\text { VALVES } \\
\text { METERS } \\
\text { PUMPS } \\
\text { POTAL DIPING SYSIFM }\end{array}$ & $\begin{array}{r}1330.69 \\
614.19 \\
6399.29 \\
23.82 \\
801.83 \\
067.69 \\
59.65 \\
1722.47 \\
104.38 \\
11757.27\end{array}$ \\
\hline 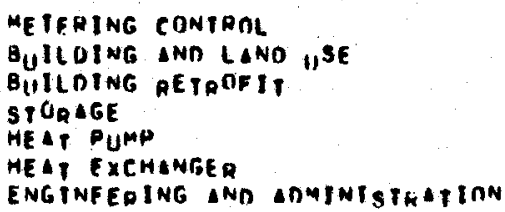 & $\begin{array}{r}117.57 \\
117.57 \\
0.00 \\
0.00 \\
0.00 \\
0.00 \\
1410.86\end{array}$ \\
\hline
\end{tabular}

OPERATING EXPENSE ACCDUNTS $(\$ \times 1000$.

$\begin{array}{lr}\text { RPERATING EXPENSES } & \\ \text { MAINTENANCE } & 40.40 \\ \text { PIIMD OPFATIION } & 86.92 \\ \text { METEQ RFADERS } & 94.04 \\ \text { MEAT PUMP OPERATION } & 33.01 \\ \text { SHPDLEMENTAL HEAT } & 0.00 \\ \text { HEATEXCANGER OPERATION } & 394.77 \\ \text { HET } & 0.00\end{array}$

TOTAL OPERATING EXPENSES GSO.00 
OISTAIAUTIONGSSTEM OESERIPTION

\begin{tabular}{|c|c|c|c|c|c|c|}
\hline $\begin{array}{c}0151 \\
\text { NO }\end{array}$ & $\begin{array}{l}\text { POYAL PEAK } \\
\text { HEAT DEMAND } \\
\text { (MATUIHR) }\end{array}$ & $\begin{array}{l}\text { HNIT } \\
\text { TEMP } \\
\text { MEOP } \\
\text { (F) }\end{array}$ & $\begin{array}{l}\text { UNII } \\
\text { FLOW } \\
\text { ATEE } \\
\text { CLANQ }\end{array}$ & $\begin{array}{l}\text { FOTAL PEAK } \\
\text { FLUYD OEMLNO } \\
\text { (KLANHR) }\end{array}$ & $\begin{array}{l}\text { ANNGAL } \\
\text { HEAY } \\
\text { DEMAND } \\
\text { TTATUI }\end{array}$ & $\begin{array}{l}\text { DISTR } \\
\text { SYSIEM } \\
\text { COSIS } \\
\text { (SH) }\end{array}$ \\
\hline $\begin{array}{l}01 \\
02 \\
03 \\
03 \\
04 \\
05 \\
06\end{array}$ & $\begin{array}{l}51.310 \\
29.910 \\
14.9104 \\
50.916 \\
25.417 \\
12.229\end{array}$ & $\begin{array}{l}104.04 \\
104.8 \\
104.8 \\
1040.4 \\
104.4 \\
104.4\end{array}$ & $\begin{array}{r}567 . \\
567 . \\
428: \\
162250 \\
10117 . \\
21034 .\end{array}$ & $\begin{array}{l}490 . \\
2960 \\
71180 \\
499 \\
299 \\
1960\end{array}$ & $\begin{array}{l}.16 \\
.10 \\
024 \\
017 \\
09 \\
00\end{array}$ & $\begin{array}{r}3.900 \\
1.899 \\
4.787 \\
.621 \\
.433 \\
1119\end{array}$ \\
\hline is & $243,00 \mathrm{n}$ & 0.0 & 0. & 2305. & .19 & 11.757 \\
\hline
\end{tabular}

OISTANCE FAOM SOUPCE IN UISTR. CFNTER (MI) SOUREE HLUTO BEMPERETHAE (F)

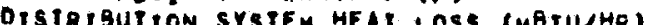

SUPPLEHENTAL HEAT PEDUIDEMENTS

DEGNEE DAYS

PERCENT OF TOTA DESIEn OEMEND

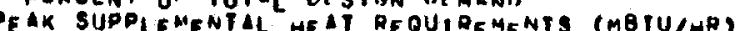

TOTAL SUPDIEMENTAL HEAT RFOUIREMENIS (MRTIUTY

\begin{abstract}
METRTE EDUTVAIENTS
\end{abstract}

\begin{tabular}{|c|c|c|c|c|c|}
\hline $\begin{array}{c}0151 \\
\text { NO }\end{array}$ & $\begin{array}{l}\text { PYAL PEAK } \\
\text { MER DEMANO } \\
\text { (MEAL OHQT) }\end{array}$ & $\begin{array}{l}\text { INII } \\
\text { IEMp } \\
\text { DQpp } \\
(C)\end{array}$ & $\begin{array}{l}\text { UNIT } \\
\text { KLON } \\
R \in I E \\
\text { (KG/HR) }\end{array}$ & 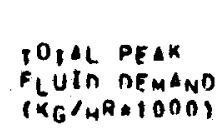 & $\begin{array}{l}\text { ANNUAL } \\
\text { HEAT } \\
\text { DEMAN } \\
\text { (GCALS }\end{array}$ \\
\hline $\begin{array}{l}01 \\
02 \\
03 \\
03 \\
04 \\
05 \\
06\end{array}$ & $\begin{array}{r}12929.679 \\
7542.093 \\
18696.120 \\
12830.237 \\
6404.901 \\
-3081.560\end{array}$ & $\begin{array}{l}58.0 \\
59.0 \\
58.0 \\
58.0 \\
58.0 \\
59.0\end{array}$ & $\begin{array}{l}257 . \\
259 . \\
194 . \\
7360 . \\
4589 . \\
9950 .\end{array}$ & $\begin{array}{l}222 . \\
130 \\
321: \\
2230 \\
112: \\
57:\end{array}$ & $\begin{array}{l}41.33 \\
24.11 \\
60.228 \\
42.97 \\
20.79 \\
10.33\end{array}$ \\
\hline orals & $614 a_{0}=5 A 7$ & 0.0 & 0. & 1065. & 198.95 \\
\hline \multicolumn{5}{|c|}{ 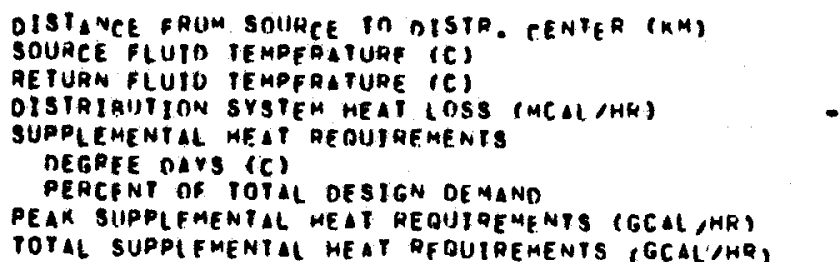 } & $\begin{array}{r}16.1 \\
100.0 \\
19.97 \\
-367.301\end{array}$ \\
\hline
\end{tabular}

10.0

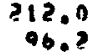

1.452

\section{TOTAL DISTRICY AREA (SHI) \\ COLDEST OAY TEMPEHATURE (F) \\ DESIGN TEMPEPATUPE (F) \\ THIL DEGPEE DAYS}

500.

3.3

$0,904.4$

DEGRE DAYS IT DESIGN TEMPENATURE

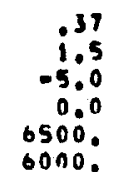

DISTR

SYSTEM

$\operatorname{cosis}$

3.900

1.899

4.187

0.023

.117

11.757
LOAD FACTOR

POTAL DISTAICT AREA (SKM)

COLOFST DAY TEMPERAIIIRF (C)

OESIGN TEMPERATURE (C)

INNIIAL DFGREE DAYS (C)

OEGREE DAYS IT DESIGN TEMPERATURE 
SAMPLE OUTPIIT FROM GEOCITY

FCONOMIC ANALYSTS FOM GEOTHERMAL DISTRICT'HEATING

\section{RESERVAIR CHAAICTFRISTICS \\ AVERAGE DEPIH \\ AVERAGE DEPIH \\ PRODUCING CAPACITY}

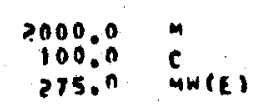

WELL DESIGN (AVEHAGE)

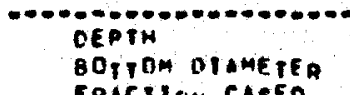

BOTTOM OTAMETE WELL PROPERIIES TIVFAACE?

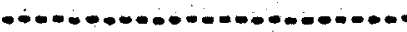

MAITHI, HELL

MW(E) , WFTL (GDOSS)

MWIE) INELL INETI

MAXIMUM ELOW QATE, WELL

HELI LIFE

DRAOUCING WELLS ON LINE

DRP wellis

INJECIION WFILS

INDUT WELL SOACING

ACqUA FIOW RATEIWE

PUTAL SLOTW RATE

WELL PRESSIJPE I SAlHKaTION

EFACTION STEAM (WELLHFin)

SIEIM SFDARATION (WELLEEAD)

STEAM,FLLSH MIX OPIION

WATER OUERPRESSURTIATION

WOJUSTEO OVERPOFESIIRTZLIION

TER PAF SSIJAE (DI ANT-FIAGHING) T34,

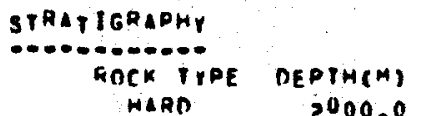

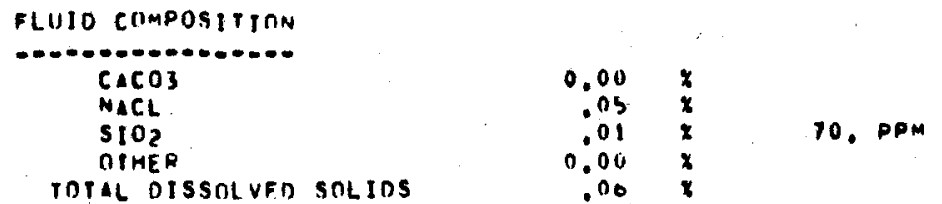

TOTAL DISSOLVED SOLIDS

PH= 7.00

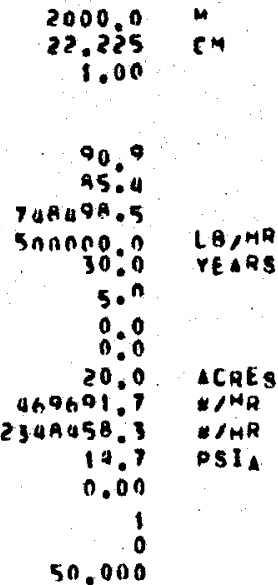

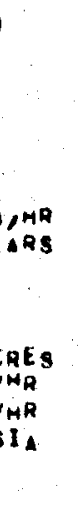

\section{NONCONDENSIRL GASES}

\begin{tabular}{|c|c|c|}
\hline $\mathrm{H}_{25} \mathrm{~S}$ & & .003 \\
\hline $\mathrm{CNO}_{2}$ & & .005 \\
\hline 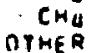 & & 0.000 \\
\hline Tural & NONC OHIDENSTHLE GASES & $.00 \mathrm{~N}$ \\
\hline
\end{tabular}
REsERUTIR ECORIOMIC DEVELOPMENT FaCtDRS

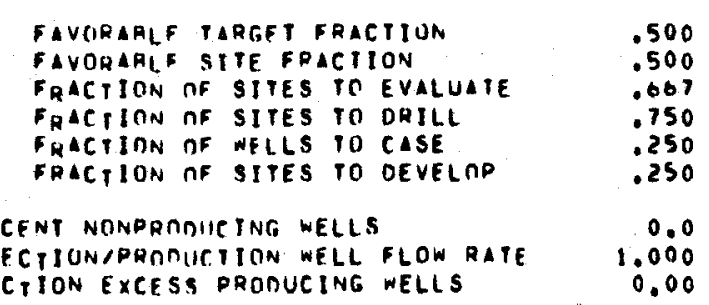


RE SERYUIR FX DLLRATION COSTIS

SAMPLE OUIPUT FROM GEOCITY

TOTAL
CAPITALIIED
(DOLLAS) EXPENSED FAVORABLE

IDENTIFICATION OF TAPGE IS litERATURE SEARCH

PRELTMINARY RETINNATSSANCE

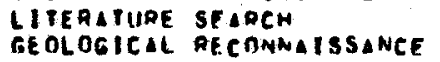

DE TALILD LANR CHEC:

DE TAILED RECONAAISSANCE

LEAgE cost

TEDCHEMICAL EXIMTNATION

REOPHYSICAL EYAMTNATION

IDENTIFICATION OF DRILI AALE SITES HEAT FI UW

TEMPFRAIIIAE GRADIENT

FLECTRICAL HESISTIVITY

MICROSE ISMIC

DEYAILED GEOCHEMISTRY

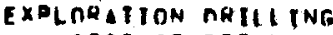

COST OF MAILLING

WELL IESTING

TOTAL EXPLORATION COST.

fielo development

PRODUCTNG WFLLS

NONPPODUCING WELIS

INJECTION WELLS

IRANGMISSION STSTEM

DISPOBAL grstFM

TOTAL FIELO DEVELOOMENT COST

FIELO OPERAITIN

REDLACFMENT WELL COST

NONPRODUCING WELL. DRILLING COS

ABANDONMENT

WE LL MAINTENANCE

OVERHEDD ANO MANAGEMENT

WELL AFrAIILLINT COS

INJECTION COST

PUMP OPEAATIONAL CAST

PRANSMISSION SYSTEM MTE.

DISPOSAL STSTEM MTF.

\begin{tabular}{|c|c|c|c|c|c|}
\hline $\begin{array}{l}124 n . \\
312 n \text {. }\end{array}$ & $\begin{array}{r}9.8 \\
24.4\end{array}$ & $\begin{array}{l}1238.3 \\
3095.7\end{array}$ & $\begin{array}{l}128 . \\
128 .\end{array}$ & $\begin{array}{l}\text { MAY/1970 } \\
\text { MAY/1970 }\end{array}$ & $\begin{array}{l}\text { oc } 1 / 1970 \\
\text { OC } 1 / 1970\end{array}$ \\
\hline $\begin{array}{l}4368 . \\
6240 \\
7488 .\end{array}$ & $\begin{array}{r}68.3 \\
97.5 \\
117.0\end{array}$ & $\begin{array}{l}4299.9 \\
6142.7 \\
7371.2\end{array}$ & $\begin{array}{l}64 . \\
64 . \\
64 .\end{array}$ & $\begin{array}{l}\text { JUN } / 970 \\
\text { JUN/1970 } \\
\text { JUN/1970 }\end{array}$ & $\begin{array}{l}\text { DEC } / 1970 \\
\text { DEC } / 1970 \\
\text { DEC } / 1970\end{array}$ \\
\hline $\begin{array}{l}197205 . \\
10238 \\
12285 \\
51109\end{array}$ & $\begin{array}{r}5850.2 \\
487.5 \\
585.0 \\
2437.6\end{array}$ & $\begin{array}{r}181355.3 \\
9750.3 \\
11700.3 \\
08751.4\end{array}$ & $\begin{array}{l}32 . \\
21: \\
21: \\
21:\end{array}$ & $\begin{array}{l}\text { JUL, } 1970 \\
\text { SEP, } 1970 \\
\text { SEP } 1970 \\
\text { SEP/1970 }\end{array}$ & $\begin{array}{l}\text { MAY/1971 } \\
\text { JUN/1971 } \\
\text { JUN/1971 } \\
\text { JUN/1971 }\end{array}$ \\
\hline $\begin{array}{l}18721 . \\
19501 . \\
5460 . \\
1800 \\
11700 .\end{array}$ & $\begin{array}{l}1170.0 \\
1219.8 \\
341.3 \\
087.5 \\
731.3\end{array}$ & $\begin{array}{r}17550.5 \\
19281.8 \\
5118.9 \\
7112.7 \\
10969.1\end{array}$ & $\begin{array}{l}16 . \\
16 . \\
16 . \\
16 . \\
16 .\end{array}$ & $\begin{array}{l}\text { APR/1971 } \\
\text { APR/1971 } \\
\text { APA } 1971 \\
\text { APH } 1971 \\
\text { APR } 1971\end{array}$ & $\begin{array}{l}\text { MAR/1973 } \\
\text { MAHA1973 } \\
\text { MAR/1973 } \\
\text { MAR/1973 } \\
\text { MAR/1073 }\end{array}$ \\
\hline $\begin{array}{r}136504 \\
3900\end{array}$ & $\begin{array}{r}11375.3 \\
975.0\end{array}$ & $\begin{array}{r}125129.7 \\
2925.1\end{array}$ & a. & $\begin{array}{l}\text { APA/1972 } \\
\text { APR/1974 }\end{array}$ & $\begin{array}{l}\text { MAR/1974 } \\
\text { APA/1974 }\end{array}$ \\
\hline $4966^{\circ} \mathrm{A}$. & 25976.4 & 460091.8 & 1.00 & & \\
\hline 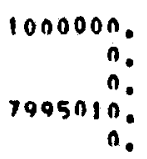 & $\begin{array}{r}333333.3 \\
0.0 \\
0.0 \\
7995010.3 \\
0.0\end{array}$ & $\begin{array}{r}066666.7 \\
0.0 \\
0.0 \\
0.0 \\
0.0\end{array}$ & & $\begin{array}{l}\text { APR/1974 } \\
\text { APR'1974 } \\
\text { OCY } 1978 \\
\text { OCY11977 } \\
\text { OCY11977 }\end{array}$ & $\begin{array}{l}\text { SEP } 11977 \\
\text { SEP } / 1977 \\
\text { DEC } 1979 \\
\text { DEC } 1979 \\
\text { DEC } 1979\end{array}$ \\
\hline
\end{tabular}

TORA FIELD OPERATION COST

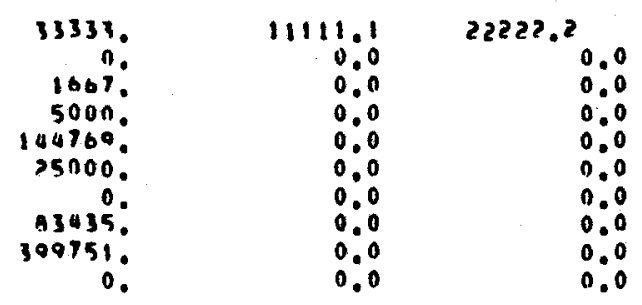

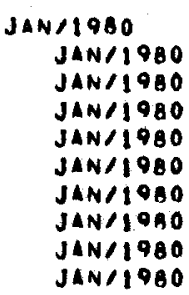

DEC 12008

OEC/2008

DEC/2009

DEC 2009

DEC/2009

DEC 12009

DEC 12009

DEC 12009

DEC/2009

692954. 
SAMPLE DUTPUT FAOM GENCITY

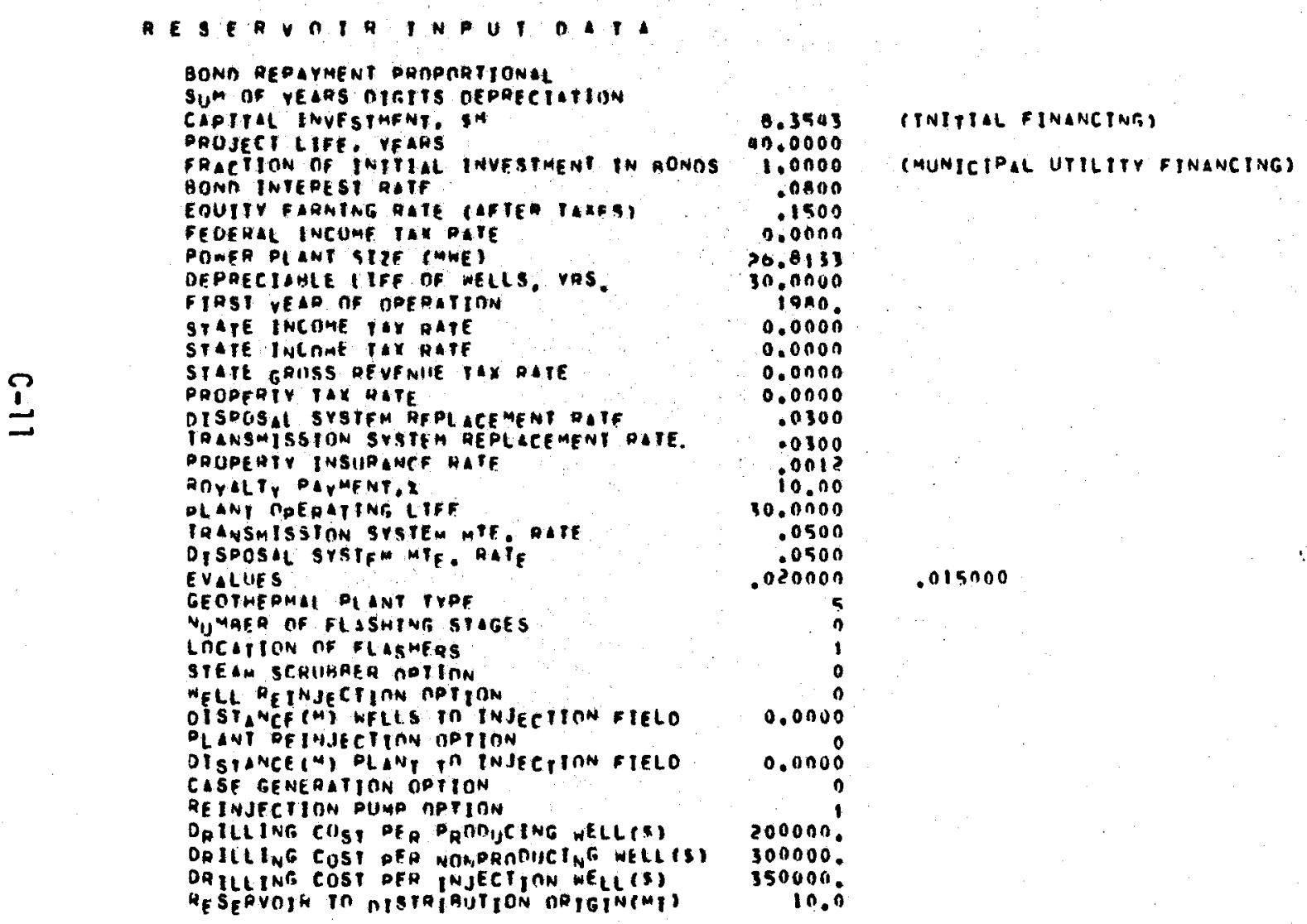


SAMPIE OUTPUI FROM GEOCTIY

ANNUAL CASH FLON DATA, EXPENSES IN SMAYR

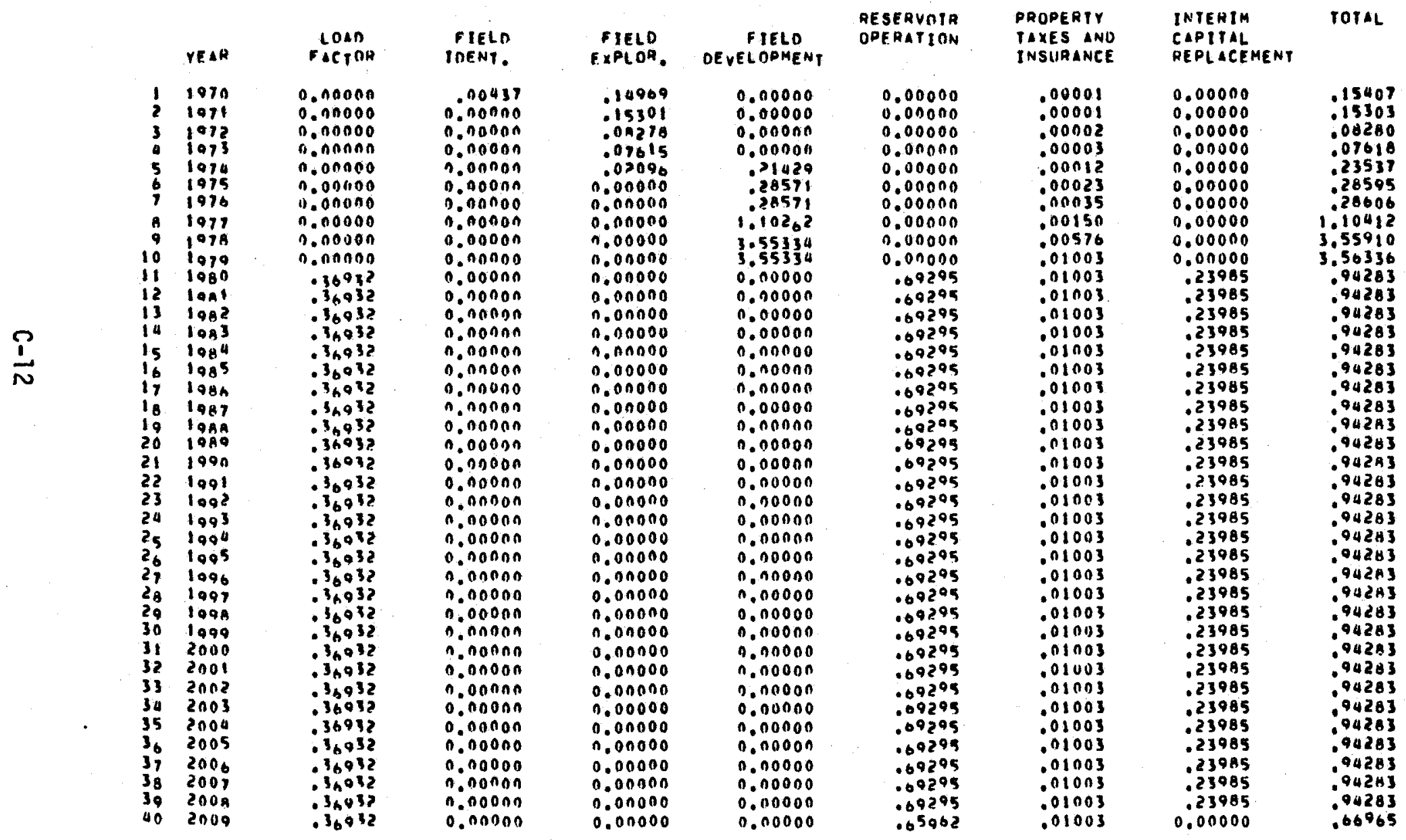


03,02177

Sample nUTPUT GROM GEOCTTY

AHNUAL OEDUCTIALE FXPENSES, EM

- Don per rieto

PAESENT OPERAYING
VEAP WOHTH FICTOH EXOESES

HONO RESERVOTR TOTAL INIERFST DEPRECIATION DEPAECIATION OPER, EXP. TAXES

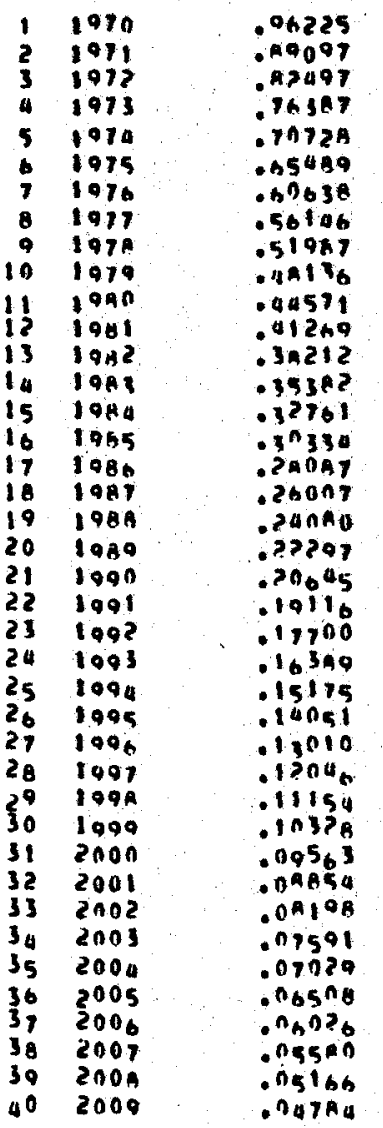

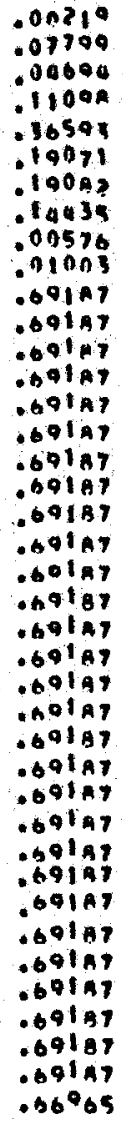

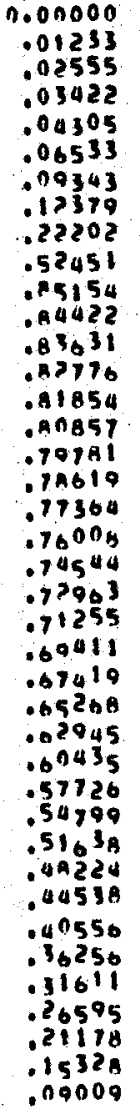

\begin{tabular}{|c|}
\hline \\
\hline 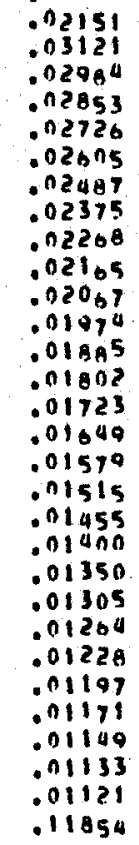 \\
\hline
\end{tabular}

0.00000

0.00000

0,00000 $0.00000 \quad .14520 \quad 0.00000$ $0.00000 \quad 0.00000$ $0.00000 \quad 0.25603 \quad 0.00000$ $\begin{array}{lll}0.0000 n & .28425 & 0.00000 \\ 0.00000 & .20814 & 0.00000\end{array}$ $0.0000 n \quad 0.00000$ $0.00000 \quad .53454 \quad 0.00000$ $.51687 \quad 2.08159 \quad 0.00010$ $.12477 \quad 2.29100 \quad 0.00000$ $.09375 \quad 2.25127 \quad 0.00000$ $.06316 \quad 2.21132 \quad 0.00000$ .63411 2.1717 0.00050 $.6060 \mathrm{~B} \quad 2.13257 \quad 0.00000$ 077000.000000 .5531? $2.05493 \quad 0.00000$ $.52819 \quad 2.01637 \quad 0.00000$ -50420 $.48143 \quad 0.000 n$ -45asa - U3a7a le.er206 .0901 1.0.000 .40027 1.7835o - Jarsa 1.70200 - 365 वि 1.702801 - 1.61030 $3556 ?$
37504 1.53124 1.53154 .29797 1287 a

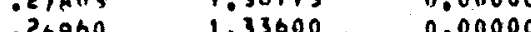
.56940 1.336100 .25??1 $.2505 ?$ $.2402 ? \quad 1.10257 \quad 0.00000$

rorts:

2.50150

3.43979

0.00000 
SIMPLE OUTPUT FHOM GEOCITY

INNUAL INCOME STATEMENT, SM

\begin{tabular}{|c|c|c|c|}
\hline VEAR & $\begin{array}{l}\text { POWFE } \\
\text { INIIS } \\
\text { (T RIII) }\end{array}$ & $\begin{array}{l}\text { PDIAL } \\
\text { POWEN } \\
\text { SALES }\end{array}$ & $\begin{array}{l}\text { BY PRODUYC } \\
\text { SALES }\end{array}$ \\
\hline 1970 & 0.00000 & $0 . n n 000$ & $n, 00000$ \\
\hline 1971 & $0.0 n 000$ & n,onnon & 0.00000 \\
\hline 1972 & nonnono & O. Donon & n. Gnoovo \\
\hline 1973 & 0.00000 & o.noonn & D.nnono \\
\hline 1014 & U.0nono & o.nogon & 0.00000 \\
\hline $\begin{array}{l}1975 \\
1976\end{array}$ & n. nnonos & $0.0009 n$ & $\begin{array}{l}0.0 n 000 \\
0.0 n 000\end{array}$ \\
\hline 1917 & 0, novon & $0.000 n \theta$ & 0,00000 \\
\hline 1979 & o.onnon & 0.00000 & 0.00000 \\
\hline 1979 & D.nnonn & o.nooun & 0,00000 \\
\hline 1980 & $.{ }^{A n} \geq 31$ & 2.09547 & 0.00000 \\
\hline $\begin{array}{l}1081 \\
106 ?\end{array}$ & An231 & 2.00547 & $\begin{array}{l}0.0 n 000 \\
0.0 n n 00\end{array}$ \\
\hline 1983 & .40231 & $? .00541$ & 0.00000 \\
\hline $10 A 5$ & $\begin{array}{l}0 n 231 \\
.40231\end{array}$ & 3.00547 & $\begin{array}{l}\text { Onoono } \\
\text { nonono }\end{array}$ \\
\hline 1986. & .40231 & $2.0954 y$ & 0.00000 \\
\hline 1947 & - $9 \cap 231$ & 3.00547 & 0.00000 \\
\hline $10 A 8$ & $.4 n 231$ & 2.19547 & 0.00000 \\
\hline 1989 & $. A n \geq 31$ & 547 & $0.0 n 000$ \\
\hline $\begin{array}{l}1000 \\
100 !\end{array}$ & $=2 n>31$ & $\log ^{4} 7$ & $\begin{array}{l}0.00000 \\
0.00000\end{array}$ \\
\hline 1092 & ancराi & 30004 & 0.00000 \\
\hline 1993 & $\operatorname{Ln} 231$ & 3.00541 & 0,00000 \\
\hline 1004 & $(A \cap>31$ & $? .0,54$, & $0.0 n 0 n 0$ \\
\hline 1995 & .00231 & 2.00547 & 0.00000 \\
\hline $\begin{array}{l}1996 \\
1997\end{array}$ & Anz 31 & $? .0954 ?$ & 0.00000 \\
\hline $109 A$ & $\begin{array}{ll}0 \\
0\end{array}$ & $\because 0054$ & 0.00000 \\
\hline 1099 & - Rn $\{3 i$ & & 0.00000 \\
\hline 2000 & .01231 & & 0.00000 \\
\hline $2 n n 1$ & A $A \cap 231$ & 2.09547 & 0.00000 \\
\hline $200 ?$ & .00231 & 2.09507 & 0.00000 \\
\hline 2003 & An?31 & 2.00547 & $\begin{array}{l}0.00000 \\
0.00000\end{array}$ \\
\hline 2005 & $\begin{array}{l}A 0231 \\
: A n \geqslant 31\end{array}$ & $\begin{array}{l}2.09547 \\
2.09547\end{array}$ & $\begin{array}{l}0.00000 \\
0,00000\end{array}$ \\
\hline 2000 & $.8 n 231$ & 2.00549 & 0.00000 \\
\hline 2007 & - $A \cap \geq 31$ & 2.00547 & O. OnOnOO \\
\hline $200 A$ & .00231 & 3.09547 & 0.00000 \\
\hline 2009 & . $A 0231$ & $? .09547$ & 0.00000 \\
\hline
\end{tabular}

PERCENTAGE
DFPLETION DFPLETION
ALLOMANCE

0.00000

0.00000

0.00000

0.00000

0.00000

n.n000

0.00000

0.00000

0.nonon

0.00000

0.00000

$0.000 n$

$0.0000 n$

0.00000

$0.0000 n$

$0.0000 n$

0.00000

0.00000

0.00000
0.00000

n.,000un

$0.0000 n$

0.00000

0.00000

0,00000

o.oncens

0,00000

0.0000

0.00000

0.00000

0.00000

0.00000

0.00000

0.00000

0.00000

n. 00000

0.00000

0.00000

0.00000 PAYMFNTS EXYENTE

0.00000
0.00000
0.00000
0.00000
0.00000
0.00000
0.00000
0.00000
0.00090
0.00000
.20055
.20955
.20955
.20955
.20955
.20955
.20955
.20955
.20955
.20055
.20055
.20055
.20955
.20955
.20955
.20955
.20955
.20955
.20955
.20055
.20955
.20955
.20955
.20955
.20955
.20955
.20955
.20955
.20955
.20955
0
DEDUCI IBLE
EXPENSES

\section{.00219}

.00032

07250

- 145es

- 500

.25603

.26814

.22778

.53454
2.08159

2.29160

2.25127

2.21132

2.13257

2.09364

2.01637

1.97780

1.93940

1.90082

1.96206

1.78356

1.74360

1.70299

1.60101

1.61030
1.57590

1.5312

1.4851

1.43737

1.38773

1.35000

1.28190

1.22516

1.1025

1. 43979
TAX $\triangle$ QLE

INCOME
(FEDERAL

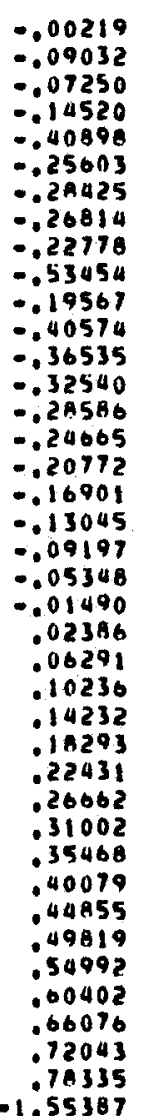

EEDERAL IAC

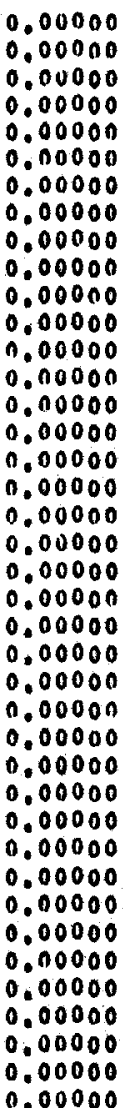


$03 / 02171$

CASH FLOM AND POWER COSTS

SAMPEF OUTPUT FRBM GEREITY

PAYOUT OF INUESTMENTS. RH

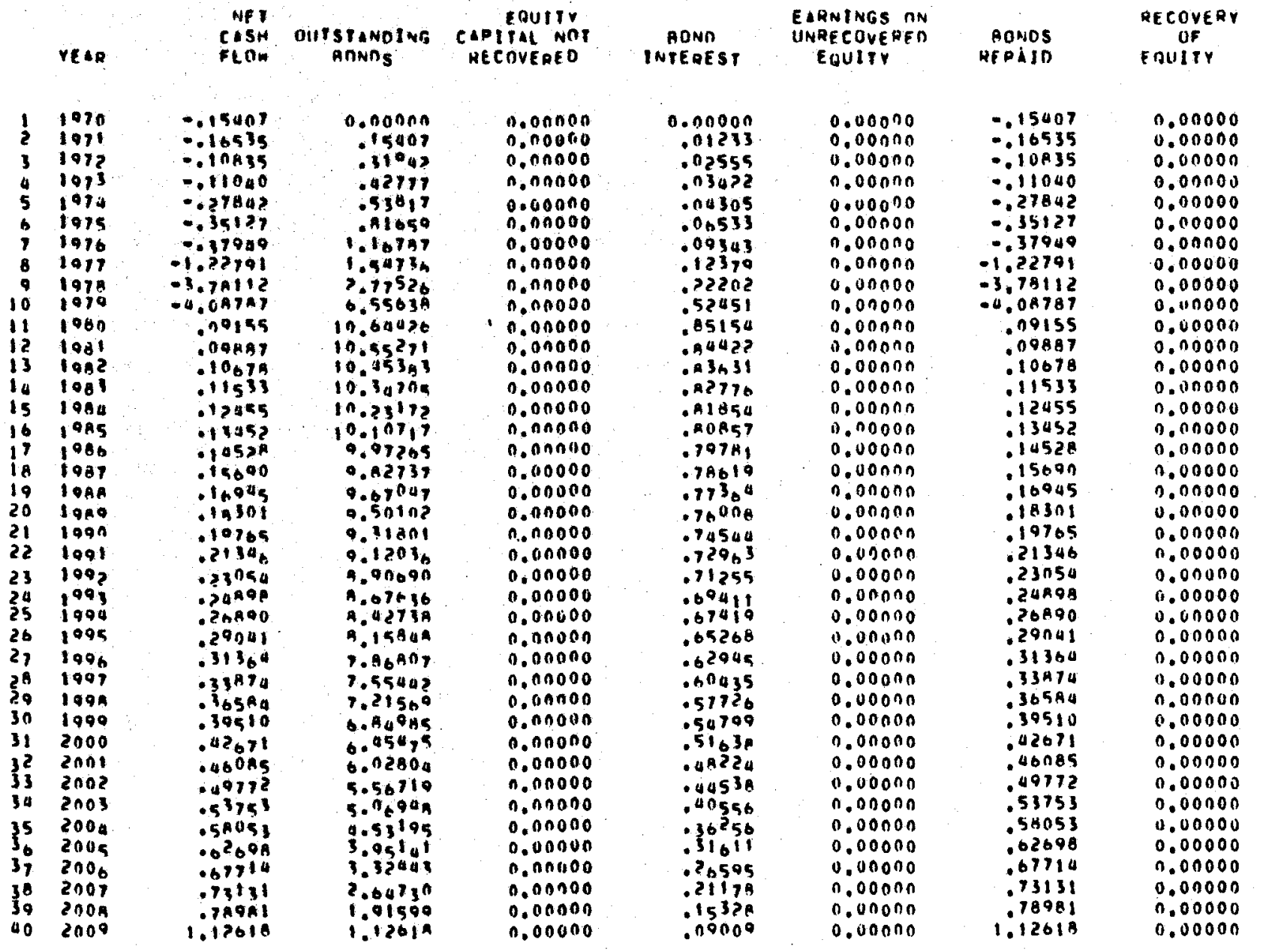


SAMPLE OUTPUT FAOM GEOCITY

COST DE ENERG

FIELD IDENTIFICATION ANR EXPLORAIION F.......................................

FIELd deVELUPMFNI (TOTAL)

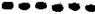

IRANSMISSION STSTEM

DISPOSAL SYSTEM

NONPRONUCING WELLS

FIELD OPEHATING COSTS (TDTAL)

$\frac{1}{a}$
DETAILEO CASH FLON OISTRIBUTION OF ENEAGY COSIS

CENTS

ANNUAL

CENTS

ANNUAL

PER MATI

2.09547

9.79499

.07859

10.88322

.08732

107.04155

.86523

119.82395

.90136

14.54153

03.30003

0,00000

0.00000

117.43421

0.00000

6.06491

99.85511

19.50418

0.00000

0.0000 A

26.11785

0.00000

0.00000

0.00000

0.00000

0.00000

261.17850

16.15725

.12903

103.66670

.83173

0.00000

0.00000

0.00000

0.00000

130.47134

1.04679

0.00000

0,00000

8.96101

.07100

99.83901

. B010?

.17367

21.67131
DROUUCING WELLS
.11667

- raAso

0.00000

0.00000

.04211

0.00000

.00471

.72092

.15048

0.00000

0.00000

.20955

0.00000

0.00000

0.00000

2.09547 rotals
261.17850

2.04547 
- C

03102187

CASH FLUW AND PONEA COSTS

PAGE 9

sampla nutpuf raOm gencitr

OISTRICI MEAIING OISTRIAUTION SYSIEH INPUT RITA

BONO REPAYMENT PROPRPIIONAT

SUM OF YEARS DIGITS DEPRECIATION

PLANT INUESTMENT.

PRUJECT LIFF, MFARS

FQACTION OF IMITIAL INUESTMENT IN AONOS I.OOOO

I

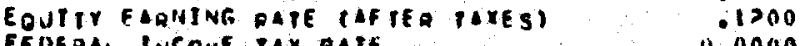

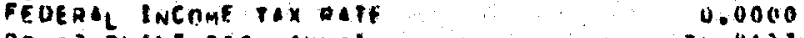

POAER PLANT SILE (HNF) 20.0133

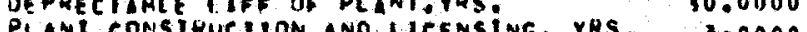

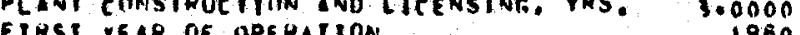

STMS TE 1060

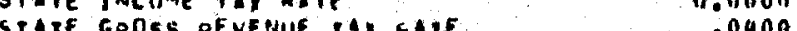

PQOPERIY TAY RATF P.000

JNIEPIM CAPIIAL REPLACEMENTS, RATEMRO

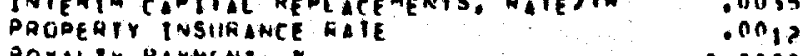

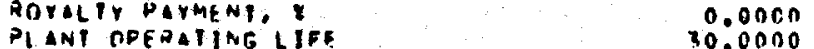

(INTTIAL FINANCING)

(MUNICTPAL UIILITY FINANCING) 
SAMPLE OUYPUT EROM GEOCITY

cash flow tarle poner plant, millions

\begin{tabular}{|c|c|c|}
\hline & IFAK & 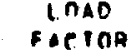 \\
\hline & 1971 & $0.00 B 00$ \\
\hline$?$ & 1918 & 0.00000 \\
\hline 3 & 1979 & 0.10000 \\
\hline $\begin{array}{l}4 \\
5\end{array}$ & 1080 & 34932 \\
\hline & 1982 & $\begin{array}{l}36937 \\
36932\end{array}$ \\
\hline & 1003 & 6032 \\
\hline $\begin{array}{l}8 \\
0\end{array}$ & 1094 & $3693 ?$ \\
\hline 10 & 1083 & $\begin{array}{l}693 ? \\
3693 ?\end{array}$ \\
\hline 11 & 1967 & $\begin{array}{l}36938 \\
36038\end{array}$ \\
\hline 12 & $\log 8$ & .36932 \\
\hline 13 & 1989 & .36932 \\
\hline $\begin{array}{l}14 \\
15\end{array}$ & 1990 & .36932 \\
\hline 15 & 1091 & 36032 \\
\hline 16 & $\begin{array}{l}109 ? \\
1003\end{array}$ & $\begin{array}{r}36932 \\
3603 ?\end{array}$ \\
\hline is & 1094 & .36032 \\
\hline 19 & 1095 & 36032 \\
\hline 20 & 1096 & $.3903 ?$ \\
\hline 21 & 1097 & .36932 \\
\hline $\begin{array}{l}22 \\
23\end{array}$ & 1998 & 3,932 \\
\hline 24 & $\begin{array}{l}1990 \\
2100\end{array}$ & $\begin{array}{l}34035 \\
3,035\end{array}$ \\
\hline 25 & 2001 & .36932 \\
\hline 26 & $200 ?$ & .36032 \\
\hline $\begin{array}{l}27 \\
28\end{array}$ & $\begin{array}{l}2003 \\
2 n 04\end{array}$ & .36932 \\
\hline 29 & 2005 & $\begin{array}{l}36432 \\
36932\end{array}$ \\
\hline 30 & $200_{b}$ & 36932 \\
\hline 31 & 2007 & \\
\hline $\begin{array}{l}32 \\
33\end{array}$ & $\begin{array}{l}2000 \\
2009\end{array}$ & - 3n932 \\
\hline
\end{tabular}

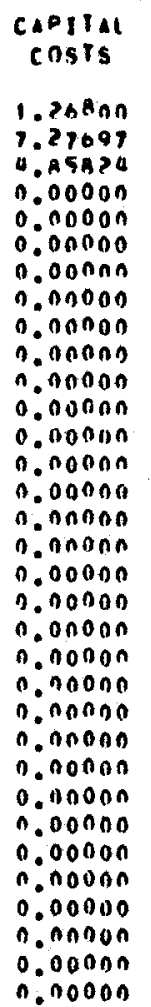

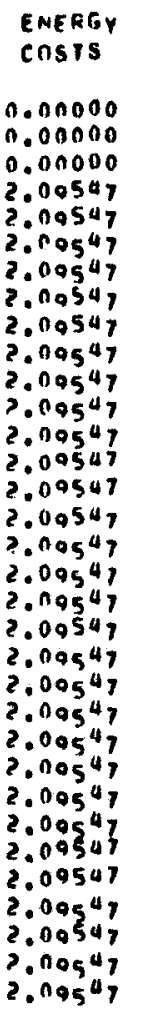

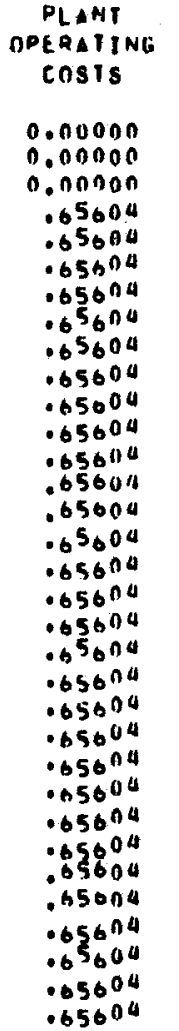

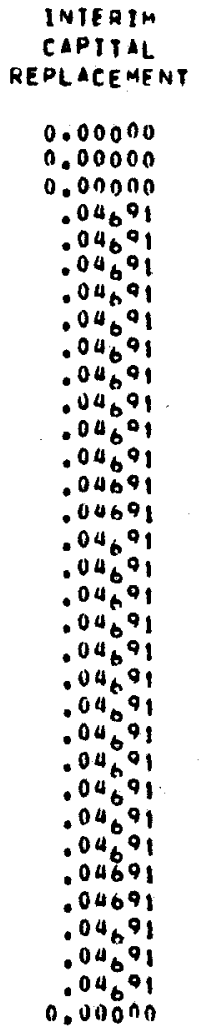

PROPERTY TAXES

0.00000 $.01025 \quad 4.06840$ .0160 2.81450 $\begin{array}{ll}.01608 & 2.81450 \\ 01608 & 2.81450\end{array}$ $.01608 \quad 2.41450$ $.01608 \quad 2.81450$ $.01600 \quad 2.81450$ $.01608 \quad 2.81450$ $.01008 \quad 2.81450$ $.01608 \quad 2.81450$ $.01608 \quad 2.81450$ $.01608 \quad 2.81450$ $.0160 \mathrm{~B} \quad 2.81050$ .01608 2.81050 2.81450 2.81450 2.81450 .0160 2.01450 2.61450 .01008 2.81050 $.01608 \quad 2.81450$ $.01008 \quad 2.81450$ $.01608 \quad 2.81450$ .0160 2.81450 .01000 2.A1450 .11600 2.81450 .01606 2.81450 $\begin{array}{ll}.01608 & 2.81450 \\ .01600 & 2.81450\end{array}$ $.01608 \quad 2,76759$ 
SAMDLE OUTPUI FRUM GEOCITY

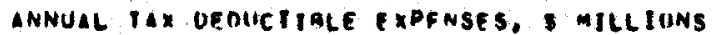

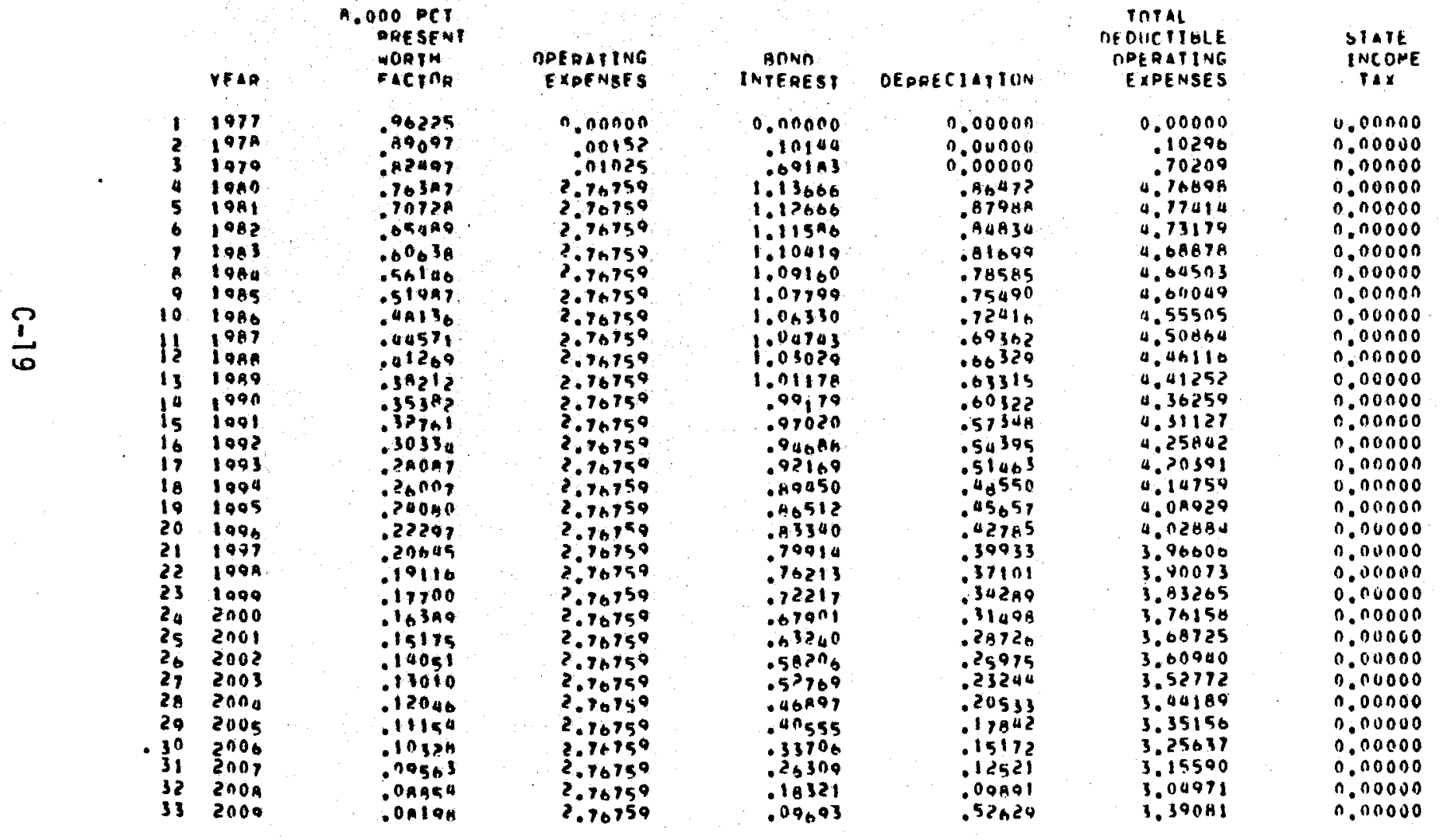


SAMPLE NUTPUT FROM GEOCITY

ANNUAL INCOME STATEMENT, S MILLIONS

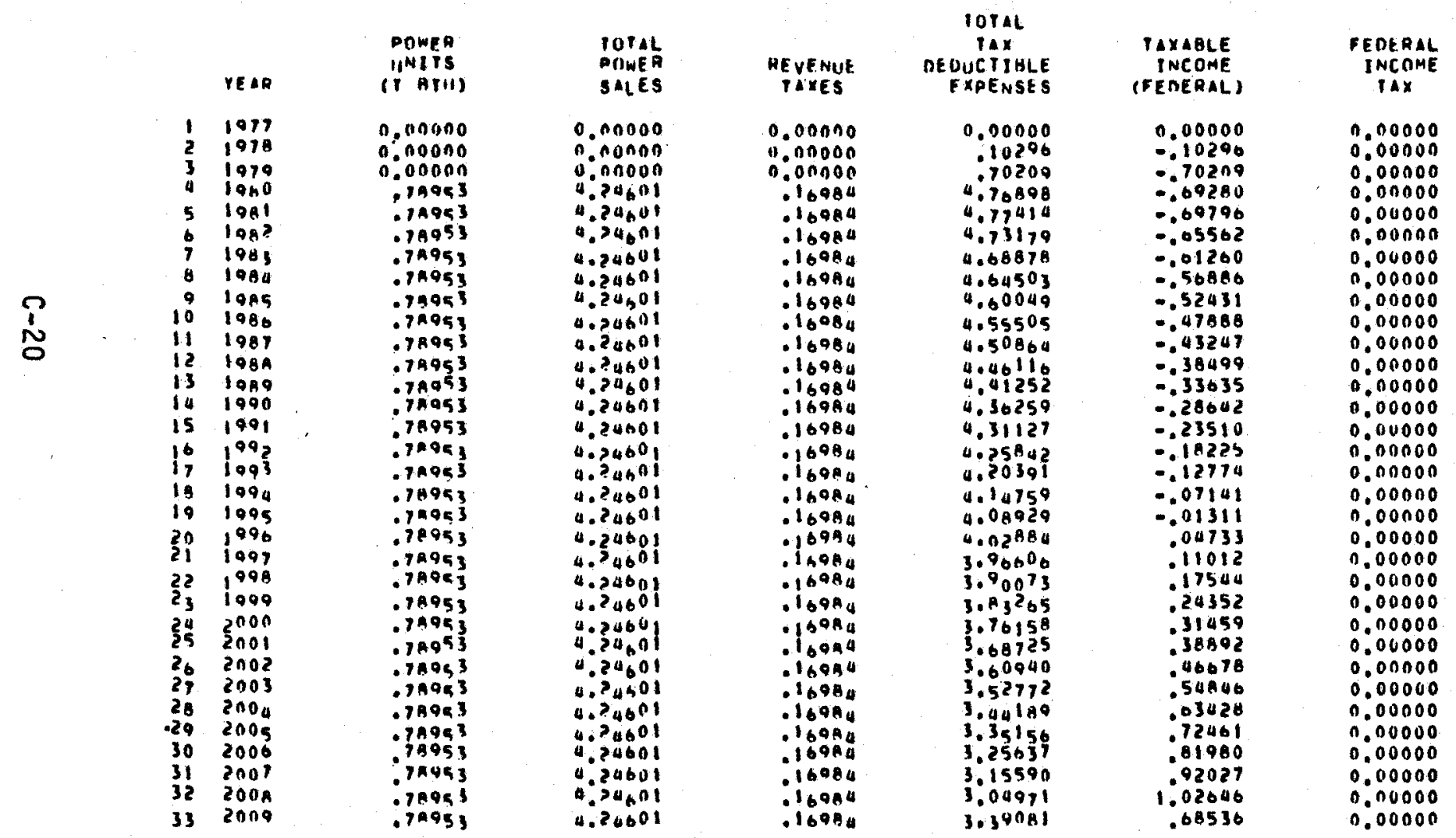


SAMPLE OUTPIIT GROM GEOCITY

parout of investments, S mILl tons

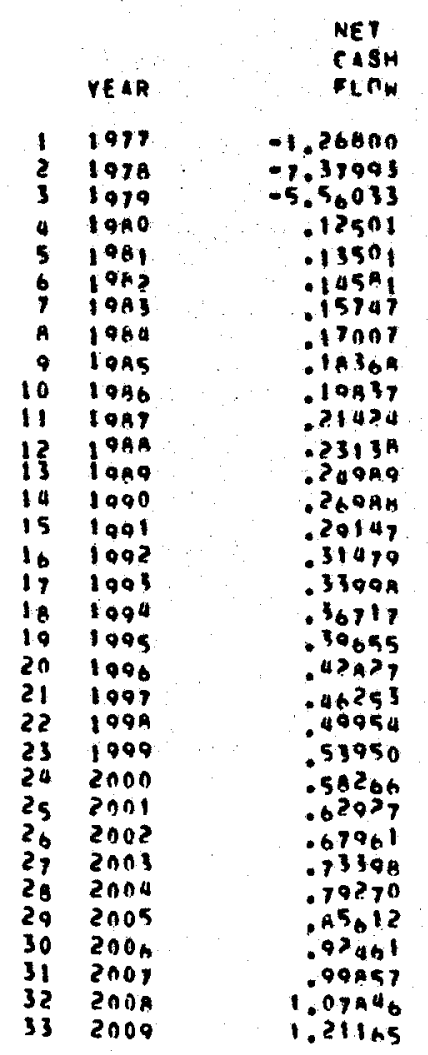

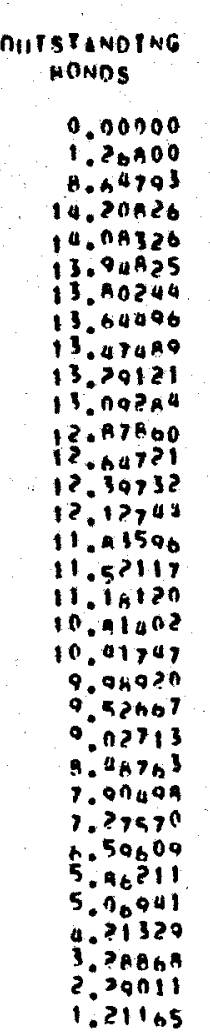

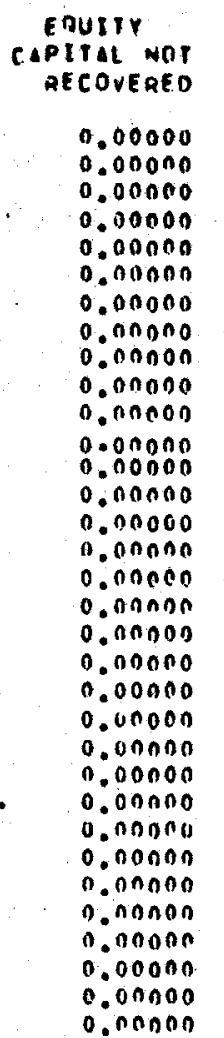

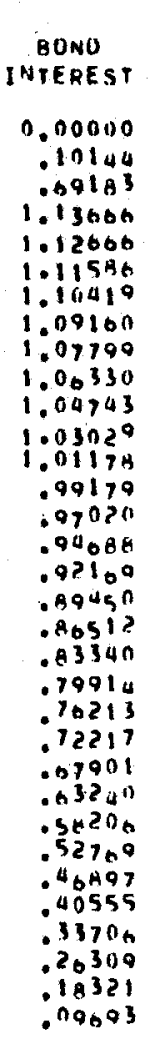
EARNINGS UN
ENAECOVEREO EDUTTY
0.00000
0.00000
0.00000
0.00000
0.00010
$0.000 n$
0.00000
0.00000
0.00000
0.00000
0.00000
0.00000
0.00000
0.00000
0.00000
0.00000
0.00000
0.00000
0.00000
0.00000
0.00000
0.00000
0.00000
0.00000
$0.0 n 000$
i. 00000
$0.0 n 000$
$0.0 n 000$
0.00000

\begin{tabular}{|c|}
\hline $\begin{array}{r}\text { BONDS } \\
\text { HEPAID }\end{array}$ \\
\hline 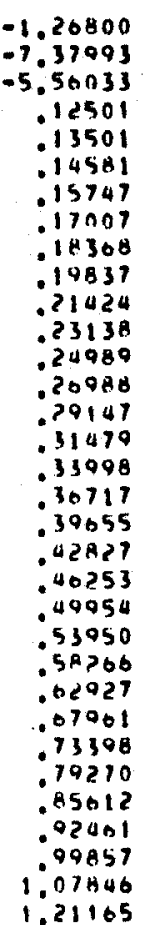 \\
\hline
\end{tabular}

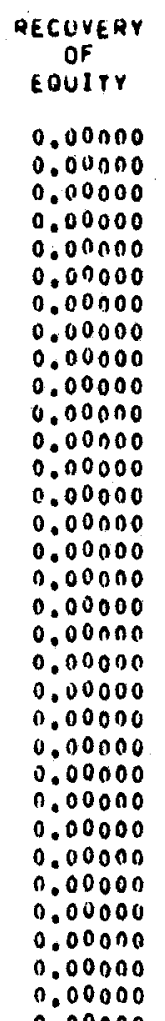

ECOVERY DUITY

0.0000

0.00000

0.00000

0.00000

0.00000

.00000

0.00 nna

0.00000

0.0000

0.00000

0.0000

0.00000

0.00000

$0.000 n$

0,00000 


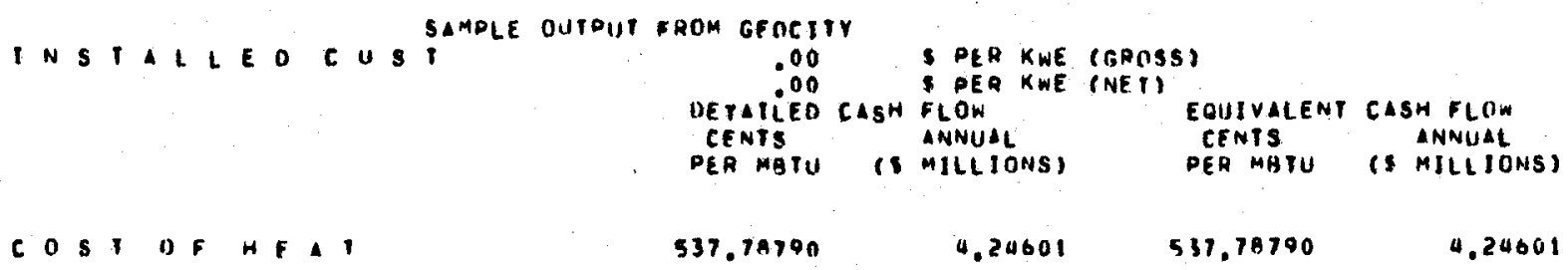

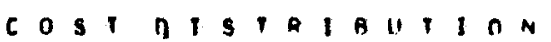

INITIAL PLANT

INTEHIM CAPITHL REPLATEMENTS

ENFRGY SUPPLY

OPERAIING EXPENSES

PROPERTY iAXES AND INgIIRANCE

SITIE hFVENIIE TLX

STATE INCOME PAX

penehal ineome ta"

BOnN INIEREST

10141

$\begin{array}{llll}159.71809 & 1.20103 & 106.37300 & 1.31357 \\ 5.09020 & .04650 & 0.13458 & .04843 \\ 205.40586 & 2.09547 & 276.46444 & 2.18278 \\ 83.09226 & .05604 & 06.55443 & .64338 \\ 2.17090 & .01714 & 2.26145 & .01785 \\ 21.51152 & .10940 & & \\ 0.00000 & 0.00000 & & \\ 0.00000 & 0.00000 & & \\ 0.00000 & 0.00000 & & \\ 537.18790 & 4.24001 & 537.78790 & \end{array}$




\section{DISTRIBUTION}

No. of

Copies

OFFSITE

A. A. Churm

ERDA Chicago Patent Group

Energy Research and Development Administration

9800 South Cass Avenue

Argonne, IL 60439

10 Inja Paik

Division of Geothermal Energy

Energy Research and Development Administration

Washington, DC 29545

390 ERDA Technical Information Center

Harry W. Falk, Jr.

Magma Power Company

P. 0. Box 9

Los Altos, CA 94022

Phil LaMori

Electric Power Research

Institute

3412 Hillview Avenue

Palo Alto, CA 94304

Magma Energy, Inc.

631 South Witmer Street

Los Angeles, CA 90017

W. Ogle

3801 B West, 44th Avenue

Anchorage, AK 99503

Vasel Roberts

Electric Power Research Institute

3412 Hillview Avenue

Palo Alto, CA 94304
No. of

Copies

OFFSITE

Mr. Roger Aureille

Chef de La Division Technique des

Energies Nouvelles

Department Systemes Energetiques

Electricite de France

Etudes et Recherches

6 , Quai Watier

78400 Chatou

France

Japan Geothermal Energy Association

Yurakucho Denki Building

1-7-1 Yuraku-Cho Chiyoda-Ku

Tokyo, Japan

Mr. Karl Omar Jonsson

Civil Engineer

FJARHITUN HF.

Alftamyri 9

Reykjavik, Iceland

Dr. 0. KappeImeyer

Federal Institute for Geosciences and Natural Resources

P. 0. Box 510153

D-3 Hanover 51

Federal Republic of Germany

Mr. Gunnar Kristinsson

Chief Engineer

Reykjavik Municipal District Heating Service

Drapuhlid 14

Reykjavik, Iceland

Dr. Gudmundur Palmason

National Energy Authority

Laugavegur 116

Reyjavik, Iceland 


\section{DISTRIBUTION contd}

No. of

Copies

OFFSITE

P. Sangnier

Conseiller Scientifique

Ministere de L'Industrie

et de La Recherche

35 Rue Saint-Dominique 75700

Paris, France

Mr. Sigurdur Thordarson

Civil Engineer and Partner

Thoroddsen and Partners

Armula 4

Reykjavik, Iceland
No. of

Copies

ONSITE

2 ERDA Richland Operations Office

Fred Goldsberry

P. G. Holsten

60 Battelle-Northwest

C. H. Bloomster (20)

J. B. Burnham

N. Carter

J. W. Currie

L. Defferding

D. E. Deonigi

L. Fassbender

J. C. Fox

H. D. Huber

G. H. Krauss

J. W. Litchfield

C. L. McDonald (10)

W. R. McSpadden

E. L. Owzarski

S. C. Schulte (10)

R. A. Walter

Economics Library (3)

Technical Information (3)

Technical Publications 